\title{
INTERACTIONS OF RADIONUCLIDES IN WATER, PARTICULATES, AND OYSTERS IN THE DISCHARGE CANAL OF A NUCLEAR POWER PLANT
}

Florence L. Harrison

Ka1 H. Wong

Rohert B. Heft

Sugust 19, $1970^{\circ}$

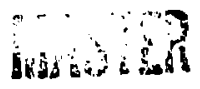

Prepared for U.S. Energy Research \& Development Administration under contract No. W-7405-Eng-48

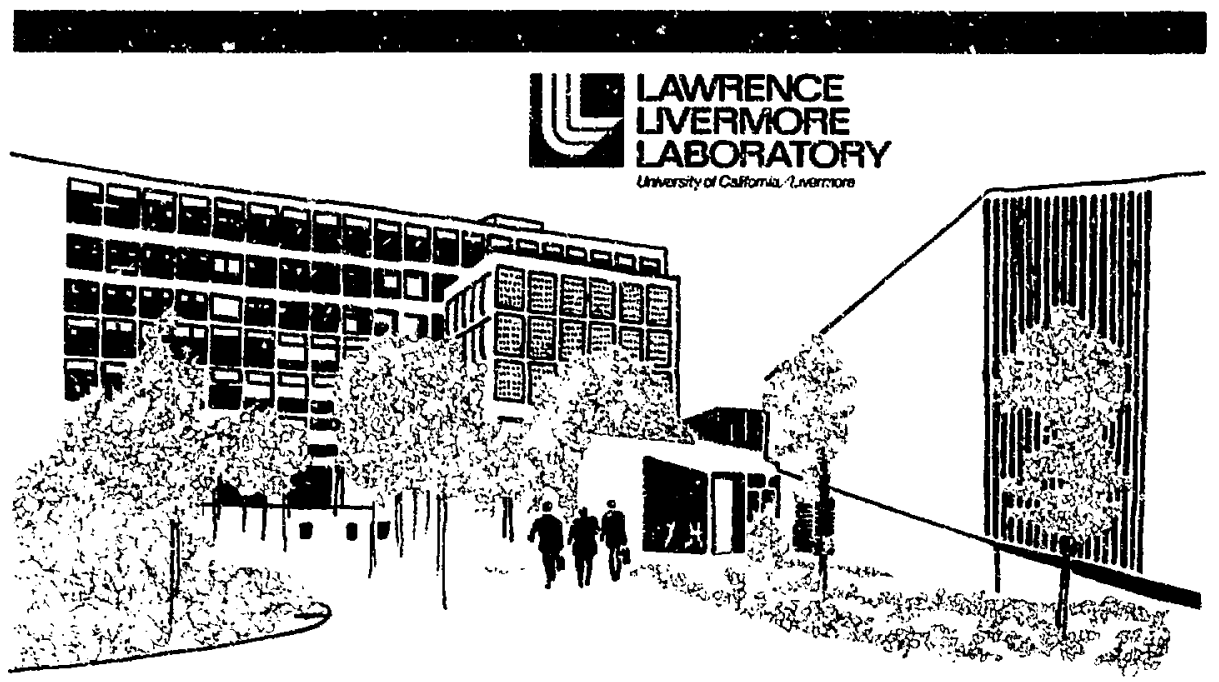




\section{NUTiCE}

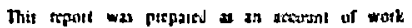

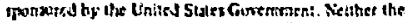

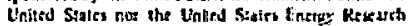

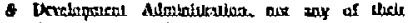

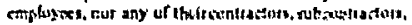

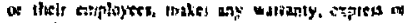

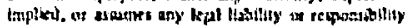

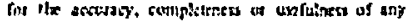

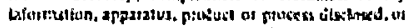

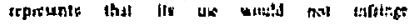

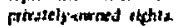

\section{NOTICE}

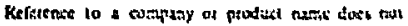

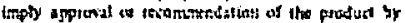

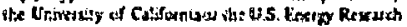

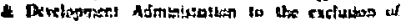

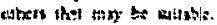

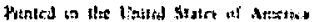

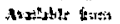

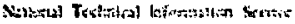

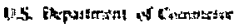

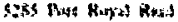

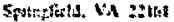

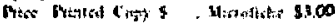

\begin{tabular}{|c|c|c|c|}
\hline Cxy thes & $\begin{array}{c}\text { Domists } \\
\text { Príes }\end{array}$ & Py tenger & $\begin{array}{c}\text { Dotinsile } \\
\text { Price }\end{array}$ \\
\hline (2) os os & $\$ 1,50$ & Antr 150 & Indos \\
\hline a?d ost & a & 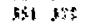 & 10.20 \\
\hline $051-05 s$ & $\leqslant .50$ & nat ans & 10.35 \\
\hline 026. 100 & $\sin$ & $401+3$ & 1100 \\
\hline 101 $1 \times 3$ & 5.50 & $526+50$ & 11,21 \\
\hline $176-150$ & 600 & 45149 & 1200 \\
\hline Ist..1?? & a.7s & $+76 \cdot 30$ & 1286 \\
\hline$\triangle 76=\geq 0$ & $74 \pi$ & 191 $\$ 35$ & 12.35 \\
\hline $30 i-205$ & 7.75 & 576.5987 & 1300 \\
\hline$\$ 26-350$ & sing & Est 575 & 1150 \\
\hline 281 245 & $\because n$ & s*as an & is.is \\
\hline$=7 \pi-40$ & 7.39 & Gill t+ & 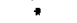 \\
\hline (51- 125 & 3.73 & & \\
\hline
\end{tabular}

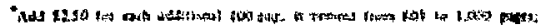

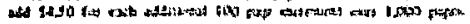




\section{屾 \\ LAWFENCE LNEAMORE LABOAATOAY \\ Universtyocicatorna Lnormore Caltom 94550}

\section{tCAL $-5197:$ \\ INTERACTIONS OF RADIONUCLIDES IN WATER, PARTICULATES, AND OYSTERS IN fHE DISCHARGE CANAL OF A NUCLEAR POWER PLANT}

Florence 4. Harrison, Kal W. Long, Robur: B. Heft

45. daEc: Aupuse 19, 1576

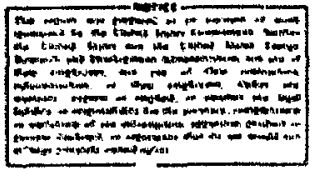




\section{Contents}

Abstract

Infooduction.

sirc Descripelon

Atitertals and Viectrods

Fxperimental station

Sampling procodures:

seaknter

parteculiegs

Oyters:

Analyelcat froceduren

Resules

Characterifation af Madionucl lde Source

Mischarge canal viater.

Rad Lonuclide concentrations dur lng stute keleasest

And lonucl lde concent rat lons Nveralfed iver

perluds of several Relastes.

Discharqe Camal fartfeulates

suspordicd parcleulacen

Serlled fartirulater

Dymates of Hidlunuelide Transfer Betien

seawater and partheulatea

Oysects

Shore-Torm Accumulacion

t.ong-Term Accumulat $\{$ on

Conceneraton Faceor:

Dlscussion and Conclusionst

Sensater

Partlculaces

Susperded fartefulates

sectled fareleulates:

Oyst.ars

Acknowledgments .

References 


\section{INTERACTIONS OF RADIONUCLIDES IN WATER, PARTICULATES, AND OYSTERS IN THE DISCHARGE CANAL OF A NUCLEAR POWER PLANT}

\section{Abstract}

This study wis designed to provide dara for dynamic modeling of radioactive pollutants in martne ecosystems adjacent to nuclear power plants. The Jata are relevant to the dynamics of radionuclide transfer among seawater, suzpended particulates, sediments, ard ilota. Gammo-emitting radionuclides $\left({ }^{54} \mathrm{Nn},{ }^{60} \mathrm{Co},{ }^{65} \mathrm{zn}\right.$, and II $\left.C_{s}\right)$ were jollowed in the water and partitulates as well as in oysters introduced into the discharge canal of the bolling water reactor of the liumoldt Bay Power l'lant near Eureka, california. The liquid waste was introduced into the canal at irregular intervals and contalned radionuci ides at extremely low hut variable concentrations. Radlonuclides were determined in the oysters, water, and particulates after single relcases (over about $6 \mathrm{hr}$ ) and over a long serien o: releases (18 morichs).

Radionuclide concencrations in the dbscharge conal water varled widely wirh tine die to Irregularity of release, differences in quantities of radtonuclides released, and varlationg in hydrological conditions. Concentrations in the seawact shanged rapidly during a release, reaching peak value. within $30 \mathrm{minu}$ es. Tíe released radionuclides were partitioned between the soluble ayd particulate phases of the water and were acrumulated in the bottom sediments. The partitioning and the amount accumulated were radionuclidedependent and varied with the biological and hydrological conditions; consistent patcerns of interchange ationg water, suspended particulates, and boctom sediments could be discerned.

Except for : adioceslum, the concentraclons in the water differed from tirose expected from the known dilution of the source mazerlal. In general, for those radionuclides with a high affinfty for particulate material, cuncentrations were more varlable and, on the average, lower than expected during releasers and higher than expected between releases. The bottor sediments in the discharge canal represent a poo: of radionuclides bound to particulaces. Resuspension of these particulates due to changing hydrologieal conditions appears to affect the concentration 
of radionuclides in tihe water between releases.

Oysters introduced into the discharge caral rapidiy accumulated the released cadionuclides. Our results Indicate that suspended partiuclates play an Important role in the accumulation of some radionuclides by oyeters. Concentration of radionuclides detected in the oysters generally reflected the levels mearured in the water and particulates. During ai perlod of high bfological productivity radionuclide accumulation rates were decreased considerably, particularly for ${ }^{60} \mathrm{Co}$, by filcration of the water in which the oyacers were maintalued. The decrease in rate appears to he related to the quantities and compositions of the particles in the water.

5or ${ }^{54} \mathrm{Hh},{ }^{60} \mathrm{Co}$, and ${ }^{65} \mathrm{zn}$ the concentration factors calculated for the oysers from the expected water concentrations were higher than those pred 1cted from the concentration factors for the corresponding stable elements. This apparent discrepancy occurs because the calculated

"expected concentrations" of radionuclides in the water do not accurately represent the concentrations avallable to the oysters. The calculations do not take into account the binding of the radionuclides to particulate mater, which increases their residence $t$ ime in the discharge canal relacive to the residence time of the water. Most models of the effects of pollutants released into ecosystems have considered the transport and motment of materials in the water ass only. It is apparent from this scudy that for radloactive or craceelemei.t pollutants with a high affintey for parciculates, It is probably necessary to model both the water mass and the sediments.

\section{Introduction}

Power plants to generate electric1ty, whether from fossil or nuclear fuels, are being locaced on escuaries or seacoasts because of the reed for coolins water. The operation of nuclear plants is actended by the release of sall quantities of liquid radloscelve wase inco the envirenmental water. Such releases are strictly controlled by the U.S. Nuclear Regulatory Commission and are kept as low as is practicable, but it is still possible that seafood arimals living In the adjacent waters may accumulate radichuclide burdens that could be cransferred to man. Current forecasts predict that the coneributions of muclear fuels to electrical power 
production in the Unl.ted States will increase signiflcantly by the year 2000. It Is important, therefore, to model the martine food chain so as to be able to assegs the maximum posstble Individual dose as well as the total population dose to man from the projected releases.

Models of the marine pathway of radionuclides to man have had two serlous Iimititions: in the absence of directily relevant data, it has frequent ly been necessary (1) to use as Input parameters the concentration factors for scable elements in the marlne inftuals, and (2) to assume that the radlonuclides are dispersed into and accureulated by the organisms solcly from the soluble phese of the water. (The concentration factor (CF) is the rat lo of the concentracion in the organism $(\mathrm{Hg} / \mathrm{g})$ co the concentration the water ( $\mathrm{Hg} / \mathrm{ml}$ ). The limitation of scable-element CF vilies is that they are usually representative of steisdy-state conditions of uptake and loss by the organism (because under nacural conditions the concencractons of the element in the ecosyscem may undergo lictle change ovez intervals of several months), whereas steady-state conditions are rately if ever attalned in such ecosystems for the radionctive igotopes of most elements (because the radioactive releases are usually intermitcent rather than cont (nuous). The linitation of assuming that the radionuclides are only in the soluble phase of the water is that they frequently interact with particulates, thereby changing their rates of dispersion and thelr avallabllities to organisms.

Since this study was initfated to provide sultable data for dynamic modeling, the data collected wert those ralevant to the dynamics of radionucilde transfer ameng wacer, susperided particulates, sediments, and biota. The site selected for the experifinent was the discharge canal of the Humbirldt Bay Power Plant operated by the laciflc las and Electrle compary. The discharge canal offers a kelarively simple model ecosystem in which the necessaty equipmenc is readily Ingtalled and serviced and in whith water, suspended particulates, and sedimencs can be conventencly sampled along with experimentally Introcluced seafood organisms. Also, radionuclide analyses of environtwencal components are facilitated by the relatively higit concentrations in tive water of the discharge canal compared to othar sices in che ecosystem that recelve the radioactive waste.

The short-terw paccerns of radionucilde cransfer among components of the ecosyscem were assegsed by examinIng at short-time intervals (1/4 to $24 \mathrm{hr}$ ) before, during, and after single 
releases, the radionucilde concentrations in the water, in the particulates, and in groups of previously unexposed oysters placed in the canal. The long-cerm pacterna were assessed by examining at long-term intervals (1 to 4 weeks) over a scries of releases, the changes in radionuclide concentrations this occurred In the water, the particulates, and the populacion of oysters Introm duced into the diacharge canal and sampled serially over an 18-month period.
This study of the eransfer of released radionuclides will contribute to our understanding of the interactions of radionuclides among the biotic and ablocte components of ecosystems and will provide the infurngcion needed for the dynamic mesteling of the case of radionctive releases. The data obtalned are teleyant also to the diapersion and accumulation of the corresponding stable isotopes when they are incroduced into marine maters as pollutants in effluents frop industrial sources.

\section{Site Description}

The Humboldt Bay Power Plant, adjacent to Huaboldt Hay near Eureka, Callfornia, produces electricity with two S4-MH(e) fossil-fuel units and a single 65-tsy(a) bofling water reactor. cooling water fros the south part of Hubolde bay is punped from an inlet cannl through the condensers of all three generating units into a discharge canal leading back to the central part of the bay (Fig. 1).

Liquid radioactive wasces froa the scuck, the power bullding and refuel. ing area, and the laundry operation are accumulated and processed at the plate. 1 at irregular intervals, 10,062- ro 40,000-2 bacches of this low-level waste are released via the discharge canal into the bay. This
18 done by puaping the waste from a storage tank into the stream of cooling water fust before it ancers che discharge canal. The concentristion of radloactivity at release are in accordance with the 1 imits prescribed by the U.S. Nuclear Regulatory Comission Administrate lon and the State of California North Coastal Reglonal Hacer Conerol Board.

The discharge canal is $140 \mathrm{~m}$ long and 12 to 21 m wlde, depending on the cide level. ${ }^{2}$ The bocton and sides consist of mud with a high content of organic material. The volume of water discharged fnto the canal depends on the nusber of units operating; the usual flow rate is abo it $40,000 \mathrm{2} /$ min (chree unics in operation). The 


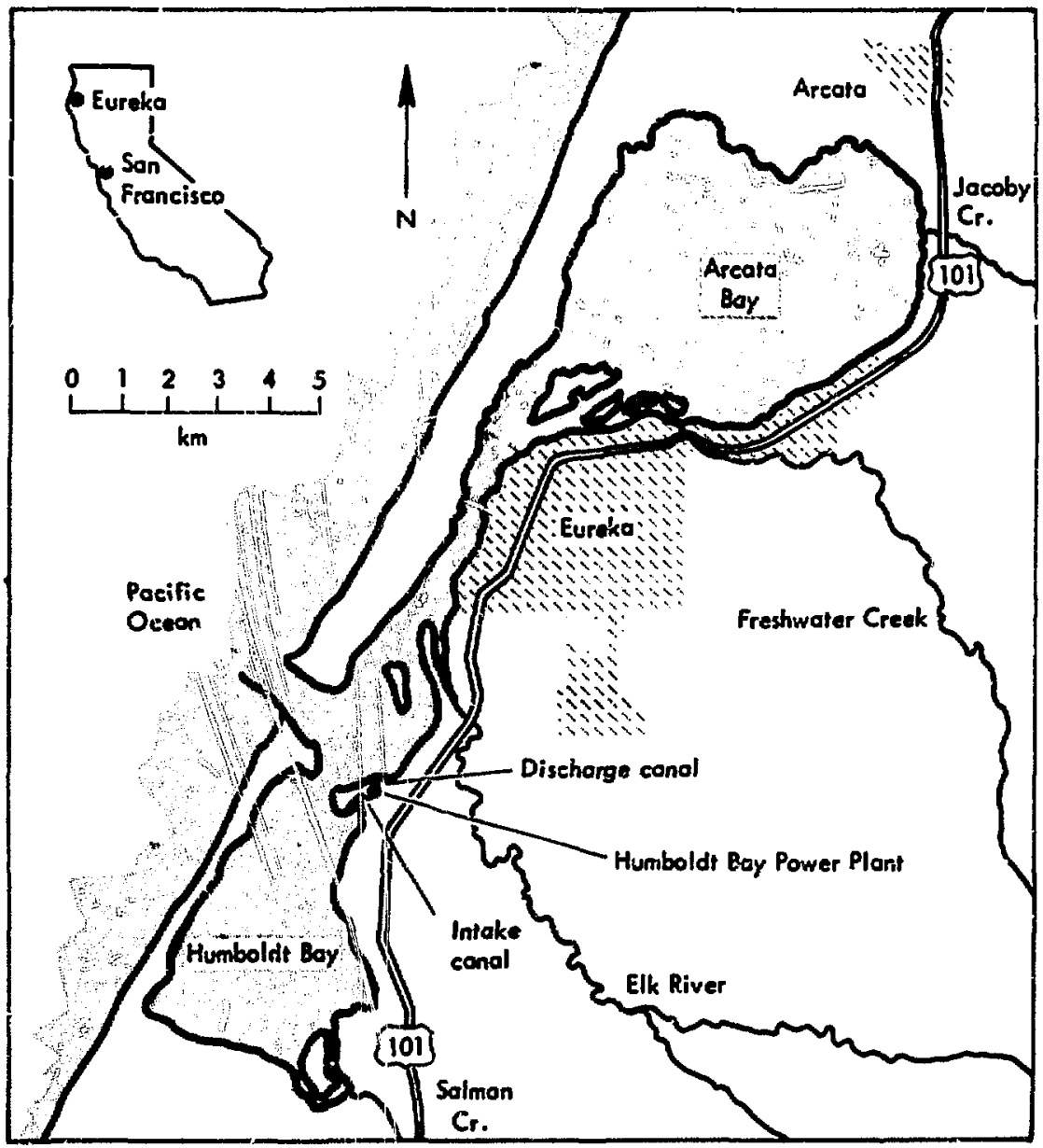

Ftg. 1. Jumbolde Bay area, showing the locacion of the Pacific Cas and Electric Huaboldt Bay Power Plant and ics discharge canol in which the experimental scation was located.

wacer cemperature usually 18 about $22^{\circ} \mathrm{C}$, but it may be higher or lower depending on the number of generating unice in operation; the temperacure
15. el evated to about $28^{\circ} \mathrm{C}$ when the effluent is hented as part of the opesation to remove mussels from the condenser tubes. 


\section{Materials anc Methods}

EXPERIMENTAL STATION

The experimental atacion tustalled at the discharge canal conolated of a redwood raft and an Instrunent shed. The raft was held in place in the center of the ranal by a system of Ines and pulleys that allowed it to be pulled Into shore at will. It wast floated on styrofoam pontoone and had openings in ity floor through which were suspende: the containera for holding oyoters in the watev streat and the trays for collecting sauples of settled particulates at the sane depth as the oysters.

The Instrument syster was cevelope: to wunitor automatically water teaperature, solar 11luminance, and conducrivicy, and to collect continuous Integrating water sampleg over preat intervals. ${ }^{3}$ A probe containing a Ge(Li) detector provided a tine history of radionuclide consentrations in the water during specific releases.

\section{SARLING PRCCEDURES}

\section{Seuvater}

Wacer samples from che discharge cant? were collected elther at selected incervals by pumping directly from the flowing stream for 15-min intervals or seasentially b; the integrating water supler with presec brief sanpling periods of preset frequencies over Intervais of one or two veeks. 3
In the first case, about 200 \& of seawater was filtered through 1-um cartridges and thell acidificd with HCl to approximately pH 1. For the sequential samples, the same volume was collected witiout filtration directy inco vessels contasing enough HCl to Lower the final voline to tpproximately pll 1 ; the collected water wat filtered just before analysis. In both cases, stable corrter was added for each radionuclide for determination of recovery.

Part 1culates

Suspended particulates were collected from the water samples elther

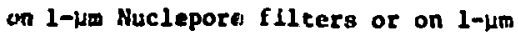
cartidge filters.

Settled particulates were sampled a: specific Incervale throughout the experimental petiod, boch from the collection trays surpended from the raft at the same level as the oysters and from weighted collcction trays placed at the bottom of the canal. at the end of the collection period, all accumuleted particulate aterial was rumoved from all collection rrays.

\section{Oyeters}

For each expirtinent, seversl hundred 3-year-old oysters (Crasbostrea gigas) obtalned from comerclal beds In the north part of Kumboldt Bay were Introduced into the diacharge cinal. The oyscers survived the 
transfer well and showed no adverse eifects irom their maintenance in the discharge canal.

\section{Shorc-Term Experimvini - Two}

releases, one in July 1973 and the other in December 1973, were studied in detail by analysis of oysters, water, and partlculates before, during, and after the reieases. In each case, the role of particulates in radionuelide uptake by the oysters was evaluated by maintaining half of the uysters in filtered water and the other hali in uniltered water.

The oysters in unfiltered water were placed in the discharge canal in plustic cages suspended from the raft. Those in filtered water were kept on the raf $x$ in aquaria supplied with discharge canal water pumped through l-im $f 1$ ter cartridges at about $30 \mathrm{k} /$ min during the release and more slowly at. other times depending on the sampling frequency. The pump Intake was in the same area as the suspended cages. Rapid turnover of aquarium wacer was Insured ty placing the inflow at the bottom of each aquarium and by keeping the cotal volume of contained water small to minimize dilution of the inflowing water.

The oysters were sampled at intervals of $6 \mathrm{hr}$ te one day. They were prepared for analysis at the site; shortly after sampling, they were removed from their shells, rinsed in filcered seawater, and pooled to give a composite sample. In these 3-yearold oysters, the soft tissues weighed about $50 \mathrm{~g}$ and the shell was ..buut $12 \mathrm{~cm}$ long.

\section{Long-Tarm Experiments - For this} experiment, all the oysters were placed in the water stream in plastic cages suspended from the raft. They were sampled at approximately 3-week incervals from August 1971 to January 1973. For each sample, oysters were romoved from the water, thelt shell lengths were measured, and the soft tissues were separated irom the shells. The soft tissues were rinsed in filtered seawater and pooled to give a conposite sample and then the sample was welghed (Table 1 ).

\section{ANALYTICAL PROCEDURES}

Processing of the seawater, oysters, and particulates was completed at Liwrence Livermore Laboratory. For the seawater samples, radionuclides of ceslum were collected onto antonium phosphomolybdate (AMP) crystals which were then isolated from tile liquid phase by filtration onto 1- $\mu m$ cartridges. Next, rad10nuclides of cobalt, manganese, and zinc were copreclpitated with ferric hydroxide, and after the precipitate had settled, the supernatant was 
discarded. Chemical yields of the isotopes were determined by atomic absurption spectrometry.

For the oyster sainples and the particulate samples from the trays, dry weights were determined after heating for a minimum of $48 \mathrm{hr}$ at $103^{\circ} \mathrm{C}$ in an oven. Ash weights were determined after ashing to constant weight at $450^{\circ} \mathrm{C}$ in a muffle furnace.
For the samples collected on cartridge filters, the cordting that made up the filter bed was first cut from the central core, weighed while wet, drled to constant weight, and ashed to remove the organic material.

All samples were counted on $\mathrm{Ge}$ (Li) detectors and the counting data were recorded on tape for computer process:ng.

Table l. Long-term oyster samples.

\begin{tabular}{|c|c|c|c|c|c|c|}
\hline $\begin{array}{c}\text { Collection } \\
\text { date }\end{array}$ & $\begin{array}{l}\text { No. of } \\
\text { oysters }\end{array}$ & $\begin{array}{l}\text { Av shell } \\
\text { length }(\mathrm{cm})\end{array}$ & $\frac{\text { Total s }}{\text { Body }}$ & $\frac{\text { sample wt }(g)}{\text { sheli }}$ & $\frac{\text { Av wt }}{\text { Body }}$ & $\frac{\text { oysters }(\mathrm{g})}{\text { Shell }}$ \\
\hline Aug. 20,1971 & 5 & - & 291 & 1245 & 58.2 & 249 \\
\hline Sept. 20,1971 & 4 & - & 283 & 1246 & 70.8 & 312 \\
\hline Oct. 19,1971 & 6 & $14.8 \pm 2.4$ & 280 & 1412 & 46.7 & 235 \\
\hline Nov. 10,1971 & 6 & $12.3 \pm 2.0$ & 252 & 1823 & 42.0 & 304 \\
\hline Jec. 28,1971 & 5 & $11.9 \pm 1.4$ & 285 & 1206 & 57.0 & 241 \\
\hline Jan. 21,1972 & 6 & $12.9 \pm 4.1$ & 310 & - & 51.7 & - \\
\hline Feb. 15,1972 & 6 & - & 229 & - & 38.2 & - \\
\hline Mar. 7, 1972 & 7 & - & 367 & - & 52.2 & - \\
\hline Mar. 29, 1972 & 7 & - & 353 & - & 50.4 & - \\
\hline Apr. 18,1972 & 7 & $11.6 \pm 2.0$ & 380 & 1781 & 54.3 & 254 \\
\hline May 16,1972 & 6 & $12.5 \pm 1.5$ & 275 & - & 45.8 & - \\
\hline June 6,1972 & 7 & $12.6 \pm 1.1$ & 283 & 1776 & 40.4 & 254 \\
\hline July 25, 1972 & 5 & $12.4 \pm 0.7$ & 261 & 1257 & 52.2 & 251 \\
\hline Aug. 22,1972 & 6 & $11.1 \pm 1.7$ & 292 & 1872 & 48.7 & 312 \\
\hline Sept. 15, 1972 & 6 & $12.1 \pm 1.4$ & 312 & 1603 & 52.0 & 267 \\
\hline Oct. 10,1972 & 6 & $12.1 \pm 1.0$ & 316 & 1719 & 52.7 & 286 \\
\hline Nov. 7,1972 & 6 & $11.7 \pm 1.9$ & 223 & 1636 & 37.1 & 273 \\
\hline Dec. 12,1972 & 5 & $11.1 \pm 1.9$ & 242 & 1328 & 48.6 & 260 \\
\hline Jan. 9, 1973 & 6 & $12.3 \pm 2.9$ & 245 & 1764 & 40.9 & 294 \\
\hline
\end{tabular}




\section{Results}

CHARACTERIZATION OF RADIONUCLIDE SOURCE

Between April 1, 1971 and December 31, 1973, an aliquot was taken from each batch of Itquid waste fust before its release into the cooling water. Each allquot was anslyzed for its content of gamna-emitting radionuclides and tritium. The radionuclides usually detected were ${ }^{3} \mathrm{H}$, ${ }^{54} \mathrm{Mn},{ }^{60} \mathrm{Co},{ }^{65} \mathrm{zm}, 134,137 \mathrm{Cg}$, and ${ }^{144} \mathrm{Ce}$. The total quantities of gamna-emitting radionuclides released are summarized briefly in Table 2.

Radionuclide concentrations varied widely from ne release to another. The releases were hlghly Irregular in frequency; during the experimental perlod, intervals between releases ranged from one to 34 days. In addition, the releases were vartable in duration, usually covering about 6 hr

Tab]e 2. Radionuclide characterization of liquid waste, April 1, 1971 to

December 31, 1973 .

Total per release ( $\mu \mathrm{C} 1$ )

\begin{tabular}{lcrc}
\hline Nuclioe & Average & Maximum & Minimum \\
${ }^{54} \mathrm{Mn}$ & 1000 & 25,000 & 2 \\
${ }^{60} \mathrm{Co}$ & 1900 & 36,000 & 22 \\
${ }^{65} \mathrm{Zn}$ & 1500 & 53,000 & 10 \\
${ }^{134} \mathrm{Cs}$ & 6100 & 61,000 & 22 \\
${ }^{137} \mathrm{Cs}$ & 9600 & 151,000 & 66 \\
${ }^{144} \mathrm{Ce}$ & 250 & 10,000 & 1 \\
\hline
\end{tabular}

but occasionally as short as $2 \mathrm{hr}$. Detalled information on the conditions of the releases, the concentrations of the radionuclides in the waste, and the total quantitles released are given in a compilation of the radiological data collected by Lawrence Livermore Laboratory personnel at the Humboldt Bay site. 4

\section{DISCHARGE CANAL WATER}

Radionuclide concentratiuns in the discharge canal water could be expected to vary widely with time for several reasons: the waste 1 tself was varlable in composition; the hydrological conditions differed from one release to another; the intervals between releases were not constant. Therefore, to document the expected varlability, ranges in concentration were determined both during time intervals when only a single release was occuring and during time intervals when several releases were occurring. Concentration ranges were determined for the former by collecting samples at specifle intervals before, during, and after releases and for the latter by collecting integrated samples over periods of one co two weeks. This documentation is important for model development, since it is useful to be able to relate the radionuclide concentrations 
in liquid waste before release to those expected for the water in which the food organisms reside.

Radionuclide Concentrations During Single Releases

Radionuclide concentrations in the discharge canal water varled during releases tot only with those in the liquid waste but also with the rate of pumping from the waste retention tank and with the rate of flow through the discharge canal. A spectific diution factor for each release was used to calculate an "expected concentration" (soluble plus particulate) for each radionuclide as it entered the discharge canal. (The dilution factor is the volume of cooling water pumped per hour divided by the volime of waste pumped into the cosling water per hour.) Hereafter, the term "expected conceintration" refers to that calculated from the dilution factor. For the three releases of concern, the quantities of each

Table 3. Time and radionuclide composition of monitored releases.

\begin{tabular}{|c|c|c|c|c|c|c|}
\hline & ${ }^{54} \mathrm{Mn}$ & ${ }^{60} \mathrm{Co}$ & ${ }^{65} \mathrm{zn}$ & ${ }^{134} \mathrm{Cs}$ & ${ }^{137} \mathrm{Cs}$ & ${ }^{144} \mathrm{Ce}$ \\
\hline \multicolumn{7}{|l|}{ Apr11 4, $1973(0700$ to 1300$)$} \\
\hline \multicolumn{7}{|l|}{ Liquid waste: } \\
\hline Total release $(\mu \mathrm{Cl})$ & 130 & 300 & 510 & 12,200 & 22,100 & 110 \\
\hline Concentration ( $\mathrm{pC} / 1$ /ter) & 4,260 & 8,870 & 16,900 & 403,000 & 732,000 & 3,500 \\
\hline \multicolumn{7}{|l|}{ Discharge canal water: } \\
\hline $\begin{array}{l}\text { Expected concentration } \\
\text { (pC1/11ter) }\end{array}$ & 1.11 & 2,32 & 4.42 & 105. & 191. & 0.91 \\
\hline \multicolumn{7}{|l|}{ July 31,1973 (0900 to 1100 ) } \\
\hline \multicolumn{7}{|l|}{ IIquid waste: } \\
\hline Total release $(\mu c 1)$ & 200 & 530 & 375 & 10,700 & 17,500 & 90 \\
\hline Concentration (pCI/11ter) & 18,800 & 49,800 & 35,100 & $2,000,000$ & $\mathbf{i}, 640,000$ & 8,000 \\
\hline \multicolumn{7}{|l|}{ Discharge canal water: } \\
\hline $\begin{array}{l}\text { Expected concentration } \\
\text { (pCi/liter) }\end{array}$ & 4.85 & 12.8 & 9.05 & 258. & 423. & 2.06 \\
\hline \multicolumn{7}{|l|}{ December 4, $1973(0930-1230)$} \\
\hline \multicolumn{7}{|l|}{ Liquid waste: } \\
\hline Total release $(\mu \mathrm{C} 1)$ & 520 & 780 & 247 & 29,100 & 38,900 & 210 \\
\hline Concentration ( $\mathrm{pCI} /$ liter) & 32,100 & 47,600 & 15,200 & $1,790,000$ & $2,390,000$ & 12,700 \\
\hline \multicolumn{7}{|l|}{ Discharge canal water: } \\
\hline $\begin{array}{l}\text { Expected concentration } \\
\text { (pci/liter) }\end{array}$ & 6.28 & 9.31 & 2.97 & 349. & 467. & 2.50 \\
\hline
\end{tabular}


radionuclide released and the

expected concentrations indicate that

the concentration of each specific

radionuclide was independent of all

ochers and that the amounts released were different for each event (Table 3).

The validity oí predicting con-

centrations in the water from the dultion of the waste was nssessed by comparing expected and measured concentrations of $\gamma$-emltting radionuclides in the discharge canal waser (soluble plus particulate) for two relc:ses (Table 4 ). Measured values

Table 4. Measured radionuclide concentrations (soluble plus particulate) as percentages of expected concentrations in the water of the discharge canal during two releases.

${ }^{54} \mathrm{Mn} \quad{ }^{60} \mathrm{Co} \quad{ }^{65} \mathrm{zn} \quad{ }^{137} \mathrm{Cs}$

April 4, $1973^{a}$

$\begin{array}{lrrrr}0800 & 65 & 43 & 65 & 92 \\ 0900 & 119 & 66 & 156 & 98 \\ 1000 & 63 & 22 & 133 & 104 \\ 1200 & 67 & 38 & 87 & 108 \\ \text { Mean } & 78 & 42 & 110 & 100\end{array}$

July $31,1973^{b}$

\begin{tabular}{rrrrr}
0900 & 40 & 52 & 36 & 56 \\
1000 & 41 & 80 & 73 & 102 \\
1100 & 71 & 69 & 50 & 57 \\
Mean & 51 & 67 & 53 & 72 \\
\hline
\end{tabular}

${ }^{a}$ Release began at 0700 and ceased at 1300 .

$\mathrm{b}_{\text {Release began at } 0900 \text { and ceased at }}$ 1100 . (expressed as percentages of expacted values) varled not only from one radior. clide to another but also from time to time during the zeleese for each radionuclide. Radiocesium data are given here and subsequently only for ${ }^{137} \mathrm{Cs}$ because $1 \mathrm{t}$ and ${ }^{134} \mathrm{Cs}$ behaved in essenclally the same fashion. No data are presented for ${ }^{144} \mathrm{Ce}$ alnce It was not generally detected in the difcharge canal water.

The agreement between measured and expected values was good for ${ }^{137} \mathrm{Cs}$ compared to that for ${ }^{54} \mathrm{Mn},{ }^{60} \mathrm{Co}$, or ${ }^{65} \mathrm{zn}$. During the release of July 31 , 1973, measured values for ${ }^{137} \mathrm{Cs}$ were lower then expected at 0900 and 1100 , probably because these two samples were collected during the beginning and end of the release pertod. Continuous monicoring of the water with a Ge(LI) detector probe showed that ${ }^{134,137} \mathrm{Cs}$ did not reach maximum concentration until about $30 \mathrm{~min}$ after the release had started. 5 The inflowing liquid waste appears to $\mathrm{mix}$ with the water already in the $\mathrm{dIs}^{\mathrm{s}}$ charge canal rather than to replace it immediately, However, homogeneity probably was achieved by the time the Inflowing water mass reached the sampling station, which was in the downstream half of the diecharge canal. Concentrations were essentially the same In water samples collected at the surface and $0.3 \mathrm{~m}$ from the bottom of the canal. 
Racionuclide Concentrations Averaged uver Perlods of Several Releases

The long-term varlability of radionuclide concentrations in the discharge canal water 1.3 nore complex than varlability during single releases because it encompasses not only variations within single releases but also the variacions in the1r frequency at d duration. To see this long-tern variablitty it is necessary to colopare concentrationg averaged over different intervals each of which includes scveral releases. Average concentrations in water can be calculated for a speciflc radionuclide over specific intervals if it is assumed that the residence time of the radionuclide in the discharge canal is the same as that of the body of water finto which it is diluted. The equation is:

$$
c=\frac{\sum_{n=1}^{n=1}\left(w_{1}\right) t_{1} / D_{1}+\left(w_{2}\right) t_{2} / D_{2}+\cdots\left(w_{1}\right) t_{1} / D_{1}}{t} .
$$

where $\Sigma=$ average concentration of radionuclide in water $(\rho C 1 / R)$ over cotal time I (hr). $W=$ radionuclide concentration in liquid waste $(\rho C 1 / 2)$. $D=$ dilution factor, $t$ = duration of release (hr). Average radionuclide concentrations in water were calculaced with Eq. for the perlod June 1972 to January 1973 during whlch one-week or two- week integratert water samples were being collecced (table s), Radioceslum was quantitated in all samples; ${ }^{54} \mathrm{gh},{ }^{60} \mathrm{Co}$, and ${ }^{65} \mathrm{z}$ werc useri.ly below the detection limbs in the samples collozted from func through September and were not analyaed in December and January. geter agreement between the measured and axpected concentrazions was ubserved for ${ }^{137}$ ce than for othor rndionuclides. Percentage values are avallable for all four radionuclides only for those samples collected during intervals from September 29 to necember 5. The average percentages over thls perlad were about 140 for ${ }^{137} \mathrm{Cs}, 9500$ for 5 in in, 2000 for ${ }^{60} \mathrm{Co}$, and 2400 for ${ }^{65} \mathrm{zn}$. The differences between masured and expected values for the four nuclides were In the order 54 in $>{ }^{60} \mathrm{Co}>{ }^{65} \mathrm{Zr}_{\mathrm{i}}>{ }^{137} \mathrm{Cs}$. Since this order is the same as that of the affinicles of the radlanuclides for partlculates, $6,7,8$ experiments were pertormed to ubcain information on tive parcitioning of the radionuclides anong the soluble phase of the water, the suspended partic lates, and the setcled particulates.

\section{DISCHARGE-CANAL PAKTICULATES}

During the experimental period, radionuclide concencratlons were determined both in suspanded particulates separated from water samples 
Table 5. Heatured rad fonuclide concentrations as percene of cxpeced concencration in the dinchinge canal vater. Seaviecr collected by the soquencial sumpler from June 1972 to Janunry 1973.

\begin{tabular}{|c|c|c|c|c|c|}
\hline Sampl & ling interval & ${ }^{137} \mathrm{cs}$ & $\overline{54}$ & ${ }^{60} \mathrm{cos}$ & $6,5, n$ \\
\hline \multirow[t]{3}{*}{ Iunt } & $13-20$ & 180 & $n 0^{i n}$ & iib & in \\
\hline & $20-27\left(\mathrm{AR}^{b}\right)$ & 1200 & $"$ & $"$ & " \\
\hline & 27-July 3(nik) & 200 & $"$ & $"$ & " \\
\hline \multirow[t]{4}{*}{ indy } & 3-11(all) & 110 & $"$ & " & " \\
\hline & $11-17$ & 60 & $"$ & $"$ & 4 \\
\hline & $17-25$ & (M) & " & $"$ & " \\
\hline & 25 -Nuk. $1(; H)$ & 170 & $"$ & $"$ & " \\
\hline \multirow[t]{4}{*}{$\lambda_{1: 1:}$} & $4-11$ & 120 & $"$ & $"$ & $"$ \\
\hline & $11-18$ & 180 & $" 1$ & 200 & * \\
\hline & $18-25(\mathrm{Nm})$ & 190 & $"$ & $\therefore D$ & $"$ \\
\hline & $25-\operatorname{sep} t .1$ & 80 & $"$ & 180 & " \\
\hline \multirow[t]{5}{*}{ Sept. } & . $1-6$ & 80 & $"$ & 24 & “ \\
\hline & $8-15(N R)$ & 370 & $"$ & sid & 4 \\
\hline & $15-22$ & 300 & $"$ & 60 & • \\
\hline & $22-27$ (NK) & 340 & $"$ & :ii) & $"$ \\
\hline & $29-0 \mathrm{CK} \cdot 13$ & 90 & 2,500 & 2,200 & 910 \\
\hline \multirow[t]{2}{*}{ oct. } & $13-27$ & 100 & 7.300 & 2,100 & 1.200 \\
\hline & $27-30$ ove 10 & sou & $\bar{y}, \hat{0} \bar{u}$ & 4,200 & 360 \\
\hline \multirow[t]{2}{*}{ Sov. } & $10-22$ & 170 & 28,000 & 1.400 & .4 .700 \\
\hline & $22-$ Dec. 5 & 100 & 180 & 360 & 45 \\
\hline \multirow[t]{4}{*}{ thes. } & $3-15$ & 340 & $i n$ & * & in \\
\hline & $19-23$ & 240 & $"$ & $"$ & " \\
\hline & $23-30$ & 210 & "• & $"$ & $"$ \\
\hline & $30-3$ an. $2(\mathrm{NA})$ & 200 & " & $"$ & $"$ \\
\hline \multirow[t]{3}{*}{ san. } & $2-S(N R)$ & 92 & $"$ & $"$ & $"$ \\
\hline & $5-7$ (NB) & 62 & $"$ & $"$ & $"$ \\
\hline & $9-12$ & 63 & $"$ & $"$ & $"$ \\
\hline
\end{tabular}

"xi), not Jetected; isi, not analyzed.

bxa, no reloases iuring sampling interval. 
and In seteled parcliculates collected at the level of the oyster containers and at the botcom of the canal.

concencrations were determined breh for short-cerm (1/4- to 6-hr or daily) and for long-term (near weekly) collection periods. Tu permit direct coparisons anong the different radionuclides for any one release or from one release to another, the measured concentrations are expressed as percent of the expected concentratzons $(p C 1 / 2)$.

\section{Suspended lartlculates}

The percentage of the total expected concentration found in the suspended parclculate varied durlitg single releases and differed great!y from one release to another (Tables 6 and 7 ), They werc highes: in the Apr11 4, 1973 relcase and lowest in the Decemer 4 , 197? release. Continuous montcoring of the portculate fraction after the decenber releage siowed periodic Increases and decreases in radionuclide recoveries (Table 7 ).

The varlations observed in the radionuclido concentration in suspended particulates, expressed on the bas is of unit volume, could have resulted etther from the same quantity of particles $\left(\mathrm{mg} / \mathrm{R}^{3}\right)$ with different affinities for radionuclides or from different guantities of particles with the same affinity for radionuclidos. the particuiate load in the discharge cinal water at the sampling st to differed from relense to release and with cire during a single release (cf. Tables 6 and 7). Examination of the percene data Indicates that the differences In concentration between releases were grenter than that which can be accounted for by diferences. in particle load. For ${ }^{54} \mathrm{Hn}$, the highese value durleng July wis 85 percent and the highest volue during necember was 35 perient but the largest particl c load during July was $28 \mathrm{mg} / \mathrm{h}$ and che largesc load duting December was $15 \mathrm{mg} / \mathrm{l}$. These data 36est tha. the radionuclide affinity of the particles was not the same in December as it was in July. These differences in af $f$ incty may reflect seasonal changes in the physical and chemical characteristics of the particles.

Radionuclide concentrations in the particulates were calculated on a por-unit-walght basls as well as on a per-unit-volume basis. Concentrations recovered in particulates (pCl/mg) per unte of radioactivity released were hIghest in April and lowest in December.

One attempt was made to look at the effect of particle slze on radionuclide partitioning between water and particulates. During the Juiy 31, 1973 release, the water samples were flltered consecutively through 10-, 5-, and 1-pm filters. For all 
Table 6. Meastired radionuclide concentrations expressed as percent: of expected concentration for the particulate and soluble fractions in dischatge canal water before, during, and of ter a release in April 1973 and snother in July 1973. The April release began on Apr $\lambda 1$ \& $z^{*}, 0700$ and ceased at 1300 . The July release began on July 31 at 0900 and ceased at 1100 .

\begin{tabular}{|c|c|c|c|c|c|c|}
\hline \multirow[b]{2}{*}{ Collection ${ }^{n}$} & \multirow{2}{*}{$\begin{array}{l}\text { Particulate } \\
\text { dry welght } \\
(\mathrm{mg} / \mathrm{R})\end{array}$} & \multicolumn{5}{|c|}{ Percent } \\
\hline & & Fraction & ${ }^{54} \mathrm{Mn}$ & $60_{\mathrm{Co}}$ & ${ }^{65} \mathrm{Zn}$ & ${ }^{137} \mathrm{Cs}$ \\
\hline$\underset{1630}{\text { Apr 11 } 3,1973}$ & 8.3 & $\begin{array}{l}\mathbf{p} \\
\mathbf{S}\end{array}$ & $\begin{array}{l}<4 \\
15\end{array}$ & $\leq 2$ & $\begin{array}{r}5^{c} \\
\leq 4\end{array}$ & $\begin{array}{r}\leq 0.02 \\
0.12\end{array}$ \\
\hline $\begin{array}{c}\text { Apri1 } 4,1973 \\
0630\end{array}$ & 7.4 & $\begin{array}{l}\mathbf{p} \\
\mathbf{s}\end{array}$ & $\frac{<4}{N A}$ & $\frac{\leq 2}{N A}$ & $\frac{<4}{N A}$ & $\begin{array}{l}\leq 0.02 \\
0.24\end{array}$ \\
\hline 0800 & 7.9 & $\begin{array}{l}\mathbf{P} \\
\mathbf{S}\end{array}$ & $\begin{array}{l}54 \\
11^{c}\end{array}$ & $\begin{array}{l}29 \\
14^{c}\end{array}$ & $\begin{array}{l}25 \\
40\end{array}$ & $\begin{array}{l}0.8 \\
91\end{array}$ \\
\hline 0815 & 7.0 & $\begin{array}{l}\mathbf{p} \\
\mathbf{S}\end{array}$ & $\begin{array}{l}37 \\
\text { NA }\end{array}$ & $\begin{array}{l}26 \\
N / 3\end{array}$ & $\begin{array}{l}22 \\
\text { NA }\end{array}$ & $\begin{array}{r}0.8 \\
\text { NA }\end{array}$ \\
\hline 0900 & 9.3 & $\begin{array}{l}\mathbf{P} \\
\mathbf{S}\end{array}$ & $\begin{array}{l}74 \\
45\end{array}$ & $\begin{array}{l}20 \\
38\end{array}$ & $\begin{array}{r}43 \\
113\end{array}$ & 0.9 \\
\hline 1000 & 12.8 & $\begin{array}{l}p \\
5\end{array}$ & $\begin{array}{l}22 \\
41\end{array}$ & $\begin{array}{l}22 \\
<2\end{array}$ & $\begin{array}{r}15 \\
118\end{array}$ & $103^{1.0}$ \\
\hline 1100 & 8.5 & $\begin{array}{l}\mathbf{p} \\
\mathbf{S}\end{array}$ & $\begin{array}{l}22 \\
\text { Nn }\end{array}$ & $\begin{array}{l}23 \\
\text { NA }\end{array}$ & $\begin{array}{l}21 \\
\text { NA }\end{array}$ & $\begin{array}{c}0.9 \\
102\end{array}$ \\
\hline 1200 & 8.1 & $\begin{array}{l}\mathbf{P} \\
\mathbf{S}\end{array}$ & $\begin{array}{l}33 \\
34\end{array}$ & $\begin{array}{l}22 \\
16\end{array}$ & $\begin{array}{l}25 \\
62\end{array}$ & ${ }_{106}^{1.9}$ \\
\hline 1400 & 3.6 & $\begin{array}{l}\mathbf{p} \\
\mathbf{S}\end{array}$ & $\begin{array}{l}14^{\mathrm{C}} \\
\mathrm{NA}\end{array}$ & $\begin{array}{l}12 \\
\text { Nล }\end{array}$ & $\begin{array}{l}13^{C} \\
N A\end{array}$ & $\begin{array}{l}0.3 \\
55\end{array}$ \\
\hline 1600 & 4.5 & $\begin{array}{l}\mathbf{p} \\
\mathbf{S}\end{array}$ & $\begin{array}{r}9^{c} \\
\leq 20\end{array}$ & $\leq 15$ & $\leq 10$ & $\begin{array}{l}\leq 0.02 \\
-0.5\end{array}$ \\
\hline 1800 & 4.1 & $\begin{array}{l}\mathbf{P} \\
\mathbf{S}\end{array}$ & $\frac{\leq 4}{N A}$ & $\mathrm{NA}^{\mathrm{C}}$ & $\begin{array}{l}<4 \\
\mathrm{NA}\end{array}$ & $\begin{array}{l}0.06^{c} \\
0.1\end{array}$ \\
\hline $\begin{array}{c}\text { July } 31,1973 \\
0810\end{array}$ & 22 & $\begin{array}{l}\mathbf{P} \\
\mathbf{S}\end{array}$ & $\leq 1$ & $\begin{array}{l}\leq 0.3 \\
\leq 0.2\end{array}$ & $\begin{array}{l}\leq 2 \\
\leq 1\end{array}$ & $\begin{array}{l}\leq 0.02 \\
0.1\end{array}$ \\
\hline 0900 & 25 & $\begin{array}{l}\mathbf{F} \\
\mathbf{S}\end{array}$ & $\begin{array}{l}29 \\
11\end{array}$ & $\begin{array}{l}22 \\
30\end{array}$ & $\begin{array}{l}15 \\
21\end{array}$ & $\begin{array}{r}1 \\
55\end{array}$ \\
\hline 1000 & 28 & $\begin{array}{l}\mathbf{P} \\
\mathbf{S}\end{array}$ & $\begin{array}{l}20 \\
21\end{array}$ & $\begin{array}{l}14 \\
66\end{array}$ & $\begin{array}{l}20 \\
53\end{array}$ & $101^{0.9}$ \\
\hline 1105 & 19 & $\begin{array}{l}\mathbf{P} \\
\mathbf{S}\end{array}$ & $\begin{array}{l}58 \\
13\end{array}$ & $\begin{array}{l}31 \\
38\end{array}$ & $\begin{array}{l}16 \\
34\end{array}$ & $\begin{array}{c}0.1 \\
57\end{array}$ \\
\hline 1200 & 18 & $\mathrm{~T}$ & NA & NA & NA & 3 \\
\hline
\end{tabular}


Table 6. (continued)

\begin{tabular}{|c|c|c|c|c|c|c|}
\hline \multirow[b]{2}{*}{ Collection ${ }^{a}$} & \multirow{2}{*}{$\begin{array}{l}\text { Particulate } \\
\text { dry weight } \\
\text { (ng/l) }\end{array}$} & \multicolumn{5}{|c|}{ Percent } \\
\hline & & Fraction ${ }^{b}$ & $54 \mathrm{kn}$ & ${ }^{60} \mathrm{Co}$ & ${ }^{6.5} 2 n$ & $137 \mathrm{cs}$ \\
\hline 1430 & 16 & $\mathbf{T}$ & NA & NA & NA & 2 \\
\hline 2000 & 13 & $\mathbf{T}$ & NA & NA & NA & 0.2 \\
\hline$\underset{0230}{\text { August } 1,1973}$ & 9 & $T$ & NA & NA & NA & 0.3 \\
\hline 0830 & 18 & $\mathbf{T}$ & Nล & NA & NA & 0.2 \\
\hline
\end{tabular}

\footnotetext{
a Time of initiation of collection; sample collected for is min.

${ }^{b} p$, particulate $(>1 \mu \mathrm{m}) ; \mathrm{s}$, soluble (<1 $\left.\mu \mathrm{m}\right)$.

$c_{\text {FSD }}>0.25$ (FSD, iractjonel seandard deviation, is the standard deviation divided by the mean.

dNA, not analyzed.
}

the radionuclides, the largest fraction of the activicy was asscciaced with the largest particulates, those retained on the 10-un filters (Table B). The largest changes in peicent with tine were observed for ${ }^{54}$ in on the 10-WD filter. In general, percents in the samples were in the order $34 \mathrm{Mn}$ $>{ }^{60} \mathrm{Co}>{ }^{65} \mathrm{Zn}>{ }^{137} \mathrm{Cg}$. The concentrathon ratios alffered not only with time but in some cases from one filter to another at a given time.

\section{Settled Parciculater}

The kind of inforation thet can be derlved about the behavior of particulates in the discharge canal obvlously depends on the frequency of sampling and the overall perlod of observation. Daily or more frequent gampling before, durting, and after a single release would give an Indica- tion of the dynamics of short-term reactions. With less frequent sampling over longer periods seasonal changes can be evaluated as well as the effect of differences in the interval between releases.

\section{Shorr-Term Behavior - Variaclons} in radionuclide concentration in che suspended p-iclculate fraction of the discharge canal water during and after releases could result from changes in the amounts resuspended from the botton gediments and/or the influx of radioactive particles recirculating from the Bay. The experinent of April 1. 1973 was set up to determine the posatble role of the bottom sed1ments in chis variation. During the relense, settled particulates were sappled serlally over the same sappling Intervals both from the trays 
Table 7. Neasured radionuclide concentrations expressed as percent of expected concentration for the particulates in discharge canal wator preceding, durtag and after a release that began on Decenber 4 at 0930 and ceased at 1240 .

\begin{tabular}{|c|c|c|c|c|c|}
\hline \multirow[b]{2}{*}{$\begin{array}{l}\text { Collection } \\
\text { thrie }\end{array}$} & \multirow{2}{*}{$\begin{array}{l}\text { Particulate } \\
\text { dry weight } \\
\text { (mg/l) }\end{array}$} & \multicolumn{4}{|c|}{ Percenc } \\
\hline & & ${ }^{54} \mathrm{Mn}$ & ${ }^{60} \mathrm{Co}$ & ${ }^{65} \mathrm{zn}$ & ${ }^{137} \mathrm{Cs}$ \\
\hline $\begin{array}{c}\text { December } 3,1973 \\
1535-1740\end{array}$ & & 0.25 & 0.11 & 2.0 & $0.01^{a}$ \\
\hline $1740-2200$ & & 0.53 & 0.62 & 0.67 & 0.02 \\
\hline $\begin{array}{l}\text { December } 4,1973 \\
2200-800\end{array}$ & & 2.2 & 1.9 & 1.8 & 0.014 \\
\hline $08.30-0930$ & & 0.2 & 0.15 & $0.64^{a}$ & 0.05 \\
\hline $0930-1030$ & & 2.8 & 4.0 & 4.1 & 0.35 \\
\hline $1030-1130$ & 14.8 & 3.5 & 4.5 & 8.4 & 0.60 \\
\hline $1130-1230$ & & 3.0 & 4.4 & 6.8 & 0.62 \\
\hline $1230-1330$ & & $0.25^{a}$ & 0.24 & $1.1^{\mathrm{a}}$ & 0.031 \\
\hline $1330-1545$ & 15.6 & 0.64 & 0.80 & 1.9 & 0.024 \\
\hline $1545-2000$ & & 0.14 & 0.10 & $0.74^{\mathrm{a}}$ & 0.003 \\
\hline $\begin{array}{l}\text { December 5, } 1973 \\
2000-0830\end{array}$ & & $0.06^{\mathrm{a}}$ & 0.10 & $\leq 0.03$ & 0.006 \\
\hline $0839-1345$ & & 2.4 & 3.0 & 1.3 & 0.049 \\
\hline $1345-1610$ & & $0.018^{a}$ & 0.40 & $\leq 0.03$ & 0.018 \\
\hline $1610-1930$ & & 0.4 & 0.50 & $\leq 0.03$ & 0.016 \\
\hline $\begin{array}{c}\text { Decenber } 6,1973 \\
1930-0830\end{array}$ & & 0.27 & 0.50 & $0.67^{a}$ & 0.014 \\
\hline $0830-1230$ & & $0.02^{\mathrm{a}}$ & $0.01^{\mathrm{a}}$ & $\leq 0.06$ & $0.001^{a}$ \\
\hline $1230-1730$ & & 1.1 & 1.2 & $1.5^{\mathrm{a}}$ & 0.027 \\
\hline $1730-2300$ & & $0.05^{\mathrm{a}}$ & $0.08^{\mathrm{a}}$ & $0.34^{a}$ & 0.003 \\
\hline $\begin{array}{c}\text { December } 7,1974 \\
2300-0830\end{array}$ & & 0.65 & 0.90 & $1.4^{\mathrm{a}}$ & 0.063 \\
\hline
\end{tabular}

a Fractional standard deviation $>0.25$.

placed on the canal bottom and from the trays suspended at the same depth as the oysters.

Collection trays were placed on the canel bottom at three different sites, the first about $20 \mathrm{ft}$ from the point of entry of ilquid waste into the canal, the second in the vicinity of the raft (about midway between the point of entry of the 11quid waste 
Table 8. The measured radinnuclide concentrations as percent of expected concentrations and the concentration ratiog in particulates during the July 31, 1973 release.

\begin{tabular}{|c|c|c|c|c|c|c|c|c|}
\hline \multirow[b]{2}{*}{$\begin{array}{c}\text { Collection } \\
\text { the }\end{array}$} & \multirow[b]{2}{*}{$\begin{array}{l}\text { Filter } \\
\text { (1⿴囗十) }\end{array}$} & \multicolumn{4}{|c|}{ Percent } & \multicolumn{3}{|c|}{ Concentration rat los } \\
\hline & & $\mathrm{Sh}_{\mathrm{Mn}}$ & ${ }^{60} \mathrm{co}$ & $65_{2 n}$ & $137 \mathrm{Cm}$ & ${ }^{60} \mathrm{Co} /{ }^{54} \mathrm{Mn}$ & $65_{2 n}{ }^{54} \mathrm{kn}$ & ${ }^{137} \mathrm{Ca} /{ }^{54} \mathrm{Mn}$ \\
\hline \multirow[t]{5}{*}{ 0900-0915 } & 1.0 & 22.0 & 17.0 & 10.0 & 0.45 & 0.77 & 0.45 & 0.020 \\
\hline & $s$ & 3.5 & 2.5 & 3.1 & 0.25 & 0.71 & 0.89 & 0.071 \\
\hline & 1 & 3.7 & 2.3 & 2.0 & 0.26 & $0, f^{\top}$ & 0.54 & 0.070 \\
\hline & Totel & 29.2 & 21,8 & 15.1 & 0.96 & & & \\
\hline & Hean rat:o & & & & & 0.70 & 0.66 & 0.05 \\
\hline \multirow[t]{5}{*}{ 1000-1015 } & 10 & 12.0 & 8.1 & 11,0 & 0.44 & 0.68 & 0.91 & 0.037 \\
\hline & 5 & 5.6 & 3.7 & 4.9 & 0.26 & 0.66 & 0.88 & 0.046 \\
\hline & 1 & 2.7 & 2.9 & 4.1 & 0.20 & 0.71 & 1.50 & 0.070 \\
\hline & Tocal & 20.3 & 13.7 & 20.0 & 0.90 & & & \\
\hline & Hean ratio & & & & & 0.68 & 1.10 & 0.051 \\
\hline \multirow[t]{5}{*}{$1105-1120$} & 10 & 47.0 & 24.8 & 13.0 & 0.10 & 0.53 & 0.28 & 0.0021 \\
\hline & 5 & 7.8 & 4.3 & 2.4 & 0.02 & 0.55 & 0.31 & 0.0026 \\
\hline & 1 & 2.7 & 1.6 & 1.1 & 0.02 & 0.59 & 0.41 & 0.0074 \\
\hline & Totel & 57.5 & 30.7 & 16.5 & 0.14 & & & \\
\hline & Hean rat to & & & & & 0.56 & 0,33 & 0.0040 \\
\hline
\end{tabular}

and the outlet into the central bay), and the third about 20 ft upatream fron the outlet. Radionuclide concentrations detected In particulates from crays located neareat the inlet were about the sane or higher than those near the aidway potnt; those closest to the outlet were the lowest (FIg. 2). The concentrations detected in particulates from the midway point varied least with tinc. The observed consistency in the concentrations ay have been due to the fact that the area wag least aubject to turbulence due to changes in flow rate and least affected by influx or back-flux of unlabeled sediments from the Bay.

The settled particulates from the uupended trays were similar in radionuclide concentration to those from the bottom traya curing the release period but lower and more variable with time in subsequent semples (F1g. 3). When the concentra. tions of ${ }^{60} \mathrm{Co},{ }^{65} \mathrm{Zn}$, and ${ }^{137} \mathrm{Cs}$ in the particuletes from bottom trajs and aupended trays are plotted againgt the concentrations of ${ }^{54} \mathrm{Mn}$, the values are distributed around a streight line (Fig. 4), as they would be if 


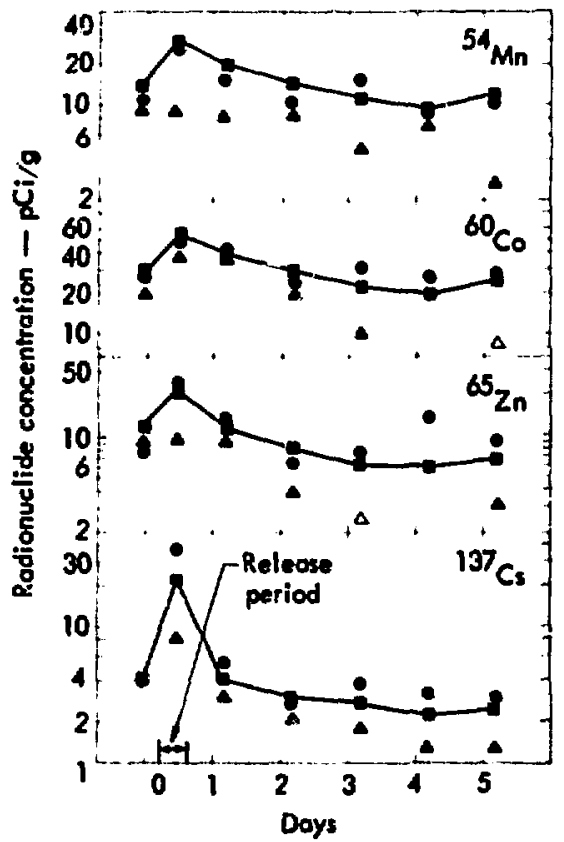

Fig. 2. Radionuclide concentrations (pCi/b dry wt) in serial samples of botton particulates from three sites in the discharge canal during the April 1973 experiment. Clrcles, 20 in downstream from the beginning of the canal; squares, near the midway point; triangles, $20 \mathrm{~m}$ upstream from the outlet. Closed aymbols, FSD $<0.2$; open symabols FSD > 0.2.

the particulates from suspended and bottom trays were deilived from the gone sururce.

Long-Tera Behavior - Radionuclide concentrations in the particulates collested on suspended erays varied

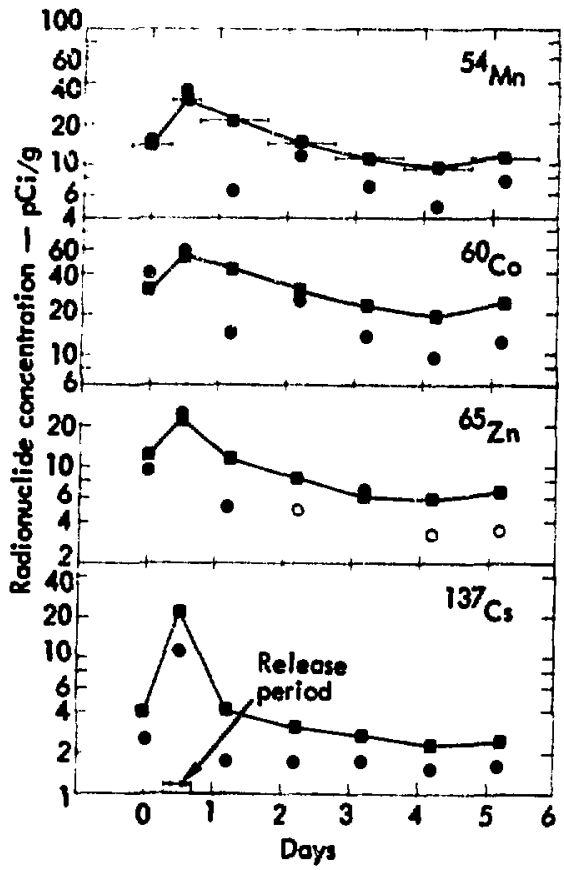

F18. 3. Radionuclide concentrations (pCi/g dry wt) in serial samples of particulates from the discharge canal during the April 1973 exper1ment. Squares, particulates collected on trays placed on the floor of the canal in the vicinity of the raft; circles, particulates collected on trays auspended from the $r$ aft at the sane level as the oyster's. The duration of the sample collaction is indicated by tine bracketed Ifnes on the square symbol on the ${ }^{54} \mathrm{Mn}$ graph. Closed symbols, FSD $<0,2$; open symbols, FSD $>0.2$. wdeity during the 16-month interval of the study. In general, the variations reflecred changes in the 
quantities of radionuclides releasco Into the discharge canal water. For ${ }^{54} \mathrm{Mn}$, the concentrations from Aarch through July ranged from about $10^{5}$ to $10^{4} \mathrm{pCr} / \mathrm{kg}$ dry weight (E1g. 5). They increased by more than an order of magnitude during the fall of 29.2 when larger quantities of ${ }^{54} \mathrm{Mn}$ were

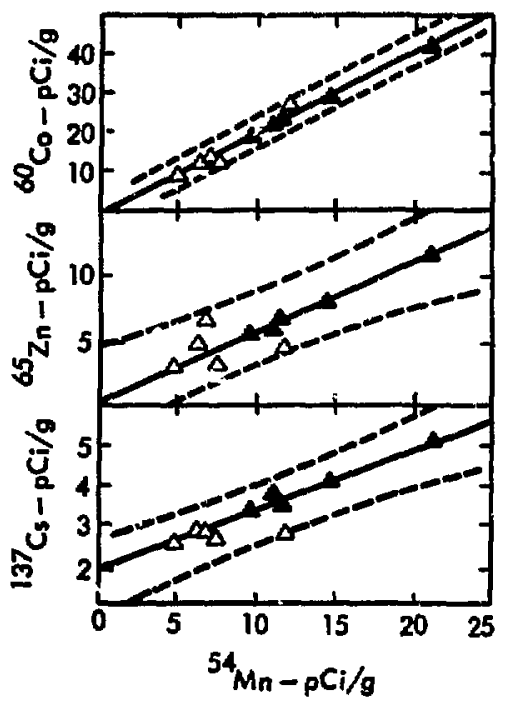

Fig. 4. Concentrations of ${ }^{60} \mathrm{Co},{ }^{65} \mathrm{zn}$, and ${ }^{137} \mathrm{Cs}$ related to those of $51 \mathrm{Mn}$ In bottom particulate samples collected during the April 1973 experiment. All concentrations are expressed on a dry weight basis. The samples art those for which daca are shown in Fig. 2. Solld triangles, botton trays; open triangles, suspended trays. Solid line regression of $60^{\circ}$, $65 \mathrm{Zn}$, or $137 \mathrm{Cs}$ concentration on 54 Mn concentration for the sample. Dashed lines indicate \pm 1 S.D. from regression for the sample. released. The highest concentration measured $\left(3.1 \times 10^{6} \mathrm{pCs} / \mathrm{kg}\right)$ was in the sample ccllected after the october 6 release. Even in those samples collisted in periods when no releases were made, the concentrations never fell below $1.5 \times 10^{3} \mathrm{pCi} / \mathrm{kg}$.

For ${ }^{60} \mathrm{Co}$, the concentrations we: usually higher than for ${ }^{54} \mathrm{Mn}$ (Fig. $y$ ), partly because more ${ }^{60}$ Co was releastid (on the average abuut twice as much). Concentrations usually were between $5 \times 10^{3}$ and $5 \times 10^{4} \mathrm{pCl} / \mathrm{kg}$ dry welght; the highest was $4.0 \times 10^{6}$ and the lowest was $3 \times 10^{3} \mathrm{pCI} / \mathrm{kg}$.

For ${ }^{65} \mathrm{zn}$, the concentrations and the patterns of variation were similax to those for ${ }^{54} \mathrm{Mn}$. The highest concentration measured was $1 \times 10^{6}$ and the levest was $7 \times 10^{2} \mathrm{pCi} / \mathrm{kg} \mathrm{dry}$ welght (F1g. 5).

For ${ }^{237} \mathrm{Cs}$, the concentrations were usually between $5 \times 10^{?}$ and $5 \times 10^{3}$ pCs/kg. The detected concentrations $f \in{ }^{1.37} \mathrm{Cs}$ were lower than those for 54 , even though most releases concained about ten times more ${ }^{137} \mathrm{Cs}$ than 54 in (F1g. 5). The highest concentration measured was $3.7 \times 10^{4}$ and the lowest was $1 \times 10^{2} \mathrm{pCi} / \mathrm{kg}$ dry welght.

The settled particulates from the suspended trays varied in quantity from $1 \mathrm{mg} / \mathrm{cm}^{2}$ to almost $12 \mathrm{mg} / \mathrm{cm}^{2}$ per day (F1g. 6). Quantities were higher in July and August than In November and December. The deposition rate may be related to the resuspension of 
bottom sediments during periods of changing hydrological conditio: $s$, but Fig. 6, which includes data on the maximum low tides, indicates no obvious relationship with the low tide level.

Dynamics of Radionuclide

l'rans - beciven seawater and purticulates

Some indication of the dynamich, of Interaction between water and particulate compartments can be obtained by following the concentration changes of radionuclides in settled particulates during intervals covering large differences in the quantities released and/or frequencies of releases. For example, there were two periods during which the Interval between releases was very large - between June 13 and July 17, 1972, and between october 6 and 27, 1972. These two periods are of special interest because before the first, the releases were relatively constant in frequency and quantity, whereas before the second, there was an unusually large release (October 6) which, in effect, pulse-labeled the system. During the June 13 - July 17 intervil ( 34 days), the concentrations in the setcled particulates showed no consistent decreases with time for any of the four radionuclides; the variations in concentrations appear to be related to changes in deposition rates (Table 9). However, during the October 6-27 Interval (21 days), there was a decrease ' $n$ the concentrations of the four radtonuclides. Particulates were collected on October 10,17, and 24; concentrations were lower or October 24 than on October 10 by a factor of 10 . The rates of change were similar for ${ }^{54} \mathrm{Mn},{ }^{60} \mathrm{Co}$, and ${ }^{65} \mathrm{Zn}$ but higher for ${ }^{137} \mathrm{Ca}$

\section{OYSTERS}

Short-time radionuclide accumulation in oysters in the discharge canal was studied during two releases by serial aampling of prevtously unexposed oysters at 6-hr to dally Intervals before, during, and after each release. In addition, long-tern accumulation over a period that encompassed a number of releases was followed in oysters sampled at near monthly intervals over a pertod of 18 months.

Short-Term Accumulation

The two release periods examined were chosen to contrast a perlod of hteqh błological productivity (July 1973) and a pertod of low blological productivity (December 1973). In each case, half the oysters were maintained in filtered seawater and the other half In unfiltered seawater.

In the July experiment, the oygters were placed In the canal water at 1700 on July 30. The prerelease sample was taken nearly $14 \mathrm{hr}$ after placement of the oysters, at 0850 on July 31. The 

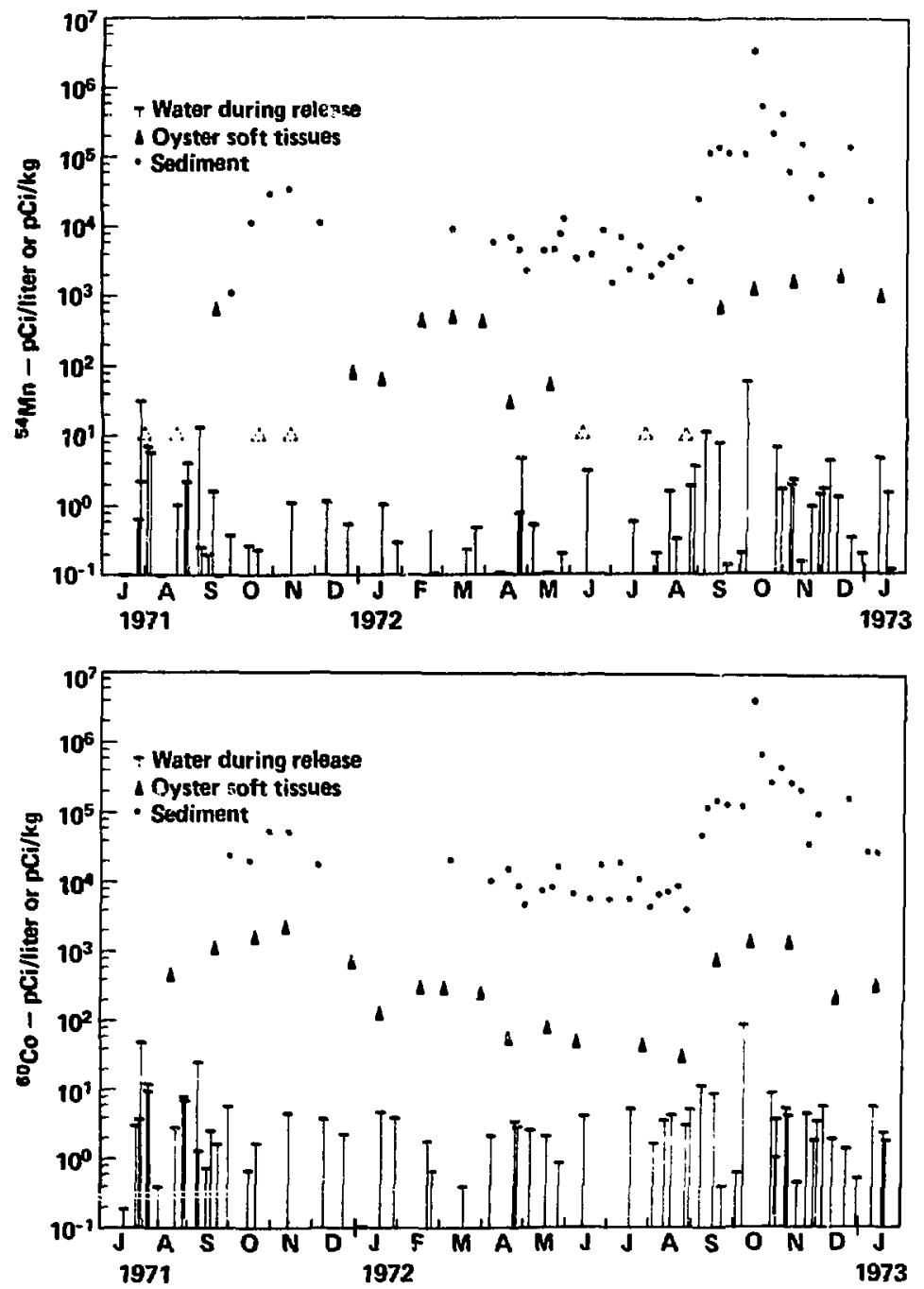

Fig. 5. Concentrations of ${ }^{54} \mathrm{Mn},{ }^{60} \mathrm{Co},{ }^{65} \mathrm{Zn}$, and ${ }^{137} \mathrm{Cs}$ in serlal samples of oyster soft tissues (closed triangles) and of particulates collected on suspended trays (circles) compared to apected concentrations in the water during releases (bars). Open trlangles, concentrations in oysters were below detection levels. 

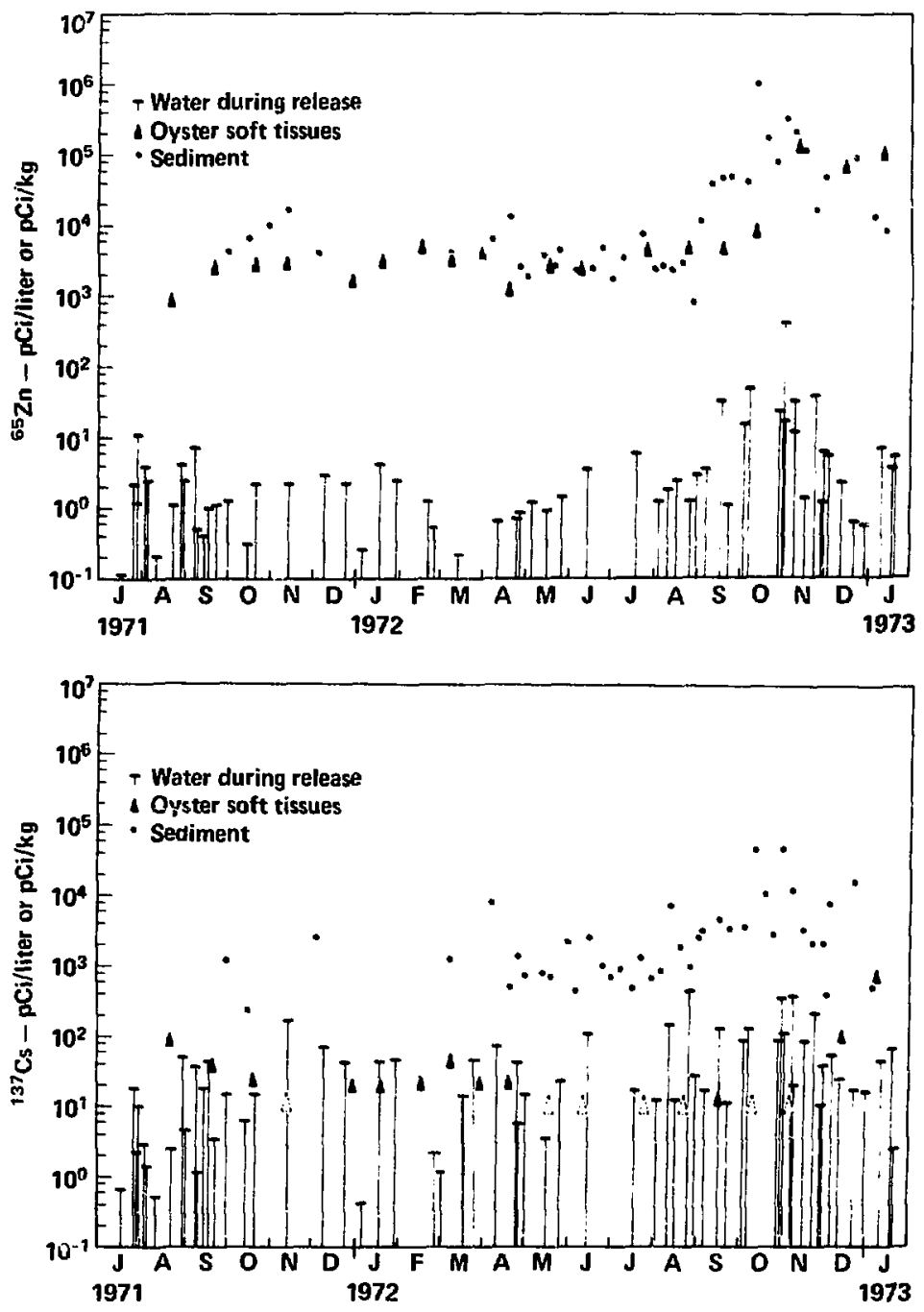

Fig. 5. (continued) 
single postrelease sample was taken about $2 \mathrm{hr}$ af ter the first sample, at 1100. The results are given in Table 10. In the prerolease oysters from unflltered water, only ${ }^{65} \mathrm{Zn}$ was detected; in those from filtered water, ${ }^{65} \mathrm{Zn}$ was higher and ${ }^{54} \mathrm{Mn}$ was detected also. The higher values obtained from filtered water may have been due to leaching of radionuclides from particulates collected on the fllterg over the $\mathrm{Q}-\mathrm{hr}$ collection perlod. Entrapment of particulates on the filter could have resulted in an increase in their normal restdence time in the discharge canal so that particles collected early in the sampling period could have been leached later by water contalning radionuclides at lower conce:ztrations. In the postrelease oysters, all radionuclides were detected in algher concentrations than in prerelease oysters and all concentrations were higher in the oysters from unfiltered water. Filtration of the seawater medium lowered the rate

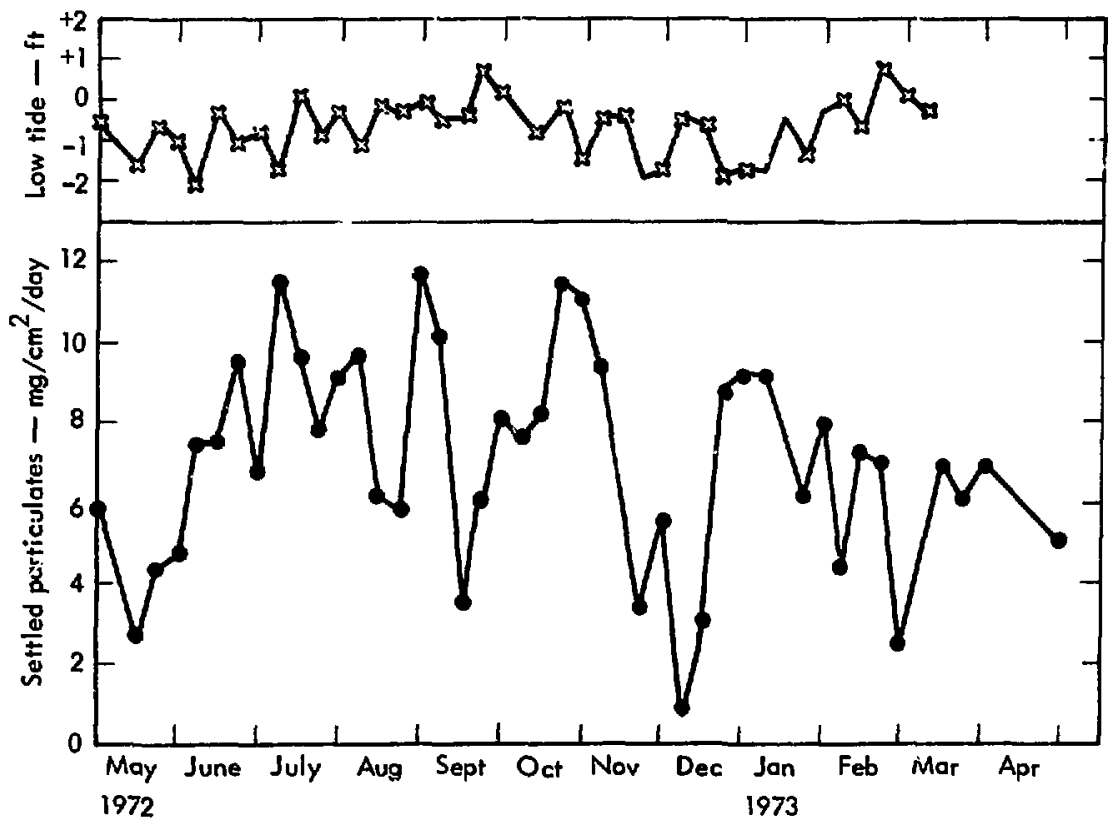

Fig. 6. Lower curve, deposition of particulates on the suspended collection trays during the 18-month experimental period. Upper curve, low tide values ( $f t$ ). 
Table 9. Concentrations of radionuclides ( $\mathrm{pCi} / \mathrm{kg}$ dry wt) in settled particulates for two intervals without releases (June 13-July 17 , 1972 and october 6-27, 1972). Also shown for each sampling interval are the deposition rates for the settled particulates and the tidal extremes.

\begin{tabular}{|c|c|c|c|c|c|c|c|}
\hline $\begin{array}{l}\text { Collection } \\
\text { date }\end{array}$ & $\begin{array}{c}\text { Deposition } \\
\text { rate } \\
\left(\mathrm{mg} / \mathrm{cm}^{2} / \mathrm{day}\right)\end{array}$ & & & ${ }^{54} \mathrm{Mn}$ & ${ }^{60} \mathrm{Co}$ & ${ }^{65} \mathrm{Zn}$ & ${ }^{137} \mathrm{Cs}$ \\
\hline June 15 & 7.6 & +7.6 & -2.2 & 3,400 & 4,900 & $1,700^{b}$ & 2,600 \\
\hline June 23 & 9.6 & +6.3 & -0.4 & 7,500 & 16,400 & $4,300^{b}$ & 990 \\
\hline June 30 & 6.8 & +6.6 & $-1,1$ & 1,600 & 4,700 & $1,500^{b}$ & 650 \\
\hline July 7 & 11.5 & +7.1 & -0.8 & 8,100 & 22,600 & $3,600^{b}$ & 960 \\
\hline July 14 & 9.2 & +7.5 & -1.8 & 1,900 & 3,900 & $N^{C}$ & 440 \\
\hline October 10 & 7.6 & +6.4 & +0.1 & $3,130,000$ & $3,990,000$ & $1,060,000$ & 43,600 \\
\hline October 17 & 8.2 & +6.0 & +0.2 & 500,000 & 640,000 & 173,000 & $? .1,100$ \\
\hline Octoher 24 & 11.6 & +7.7 & -1.5 & 210,000 & 266,000 & 70,300 & 2,800 \\
\hline
\end{tabular}

${ }^{a}$ On each collection date, all particulates were removed from each collection tray.

biractional standard deviation $>0.25$.

${ }^{\mathrm{ND}}$, not detected.

Table 10. Normalized radionuclide concentrations ${ }^{a}$ in oysters maintalned in unfiltered water in the d'scharge canal of the Humboldt Bay Power Plant during a perlod of high blological productivity (July 31, 1973) and a period of low biological productivity (December 4, 1973).

\begin{tabular}{|c|c|c|c|c|c|c|c|c|}
\hline & \multicolumn{2}{|c|}{${ }^{137} \mathrm{Cs}$} & \multicolumn{2}{|c|}{${ }^{54} \mathrm{Mn}$} & \multicolumn{2}{|c|}{${ }^{60} \mathrm{Co}$} & \multicolumn{2}{|c|}{${ }^{65} \mathrm{Zn}$} \\
\hline & $\begin{array}{c}\text { Nan- } \\
\text { filtered }\end{array}$ & F1Itrered & $\begin{array}{c}\text { Non- } \\
\text { f } 11 \text { terci }\end{array}$ & Filtered & $\begin{array}{c}\text { Non- } \\
\text { flltered }\end{array}$ & Filtered & $\begin{array}{c}\text { Non- } \\
\text { f } 11 \text { tered }\end{array}$ & Filtered \\
\hline & \multicolumn{8}{|c|}{ H1gh biologica: productivity perlod (July 1973) } \\
\hline Prerelease (pCi/kg) & ND ${ }^{b}$ & ND & ND & 9.5 & ND & ND & 17 & 22 \\
\hline Postrelease & 0.76 & 0.52 & 28 & 19.4 & 20 & 2.6 & 83 & 61 \\
\hline \multirow[t]{2}{*}{ Race $(\mathrm{pCi} / \mathrm{hr})^{\mathrm{c}}$} & 0.38 & 0,26 & 14 & 5.0 & 10 & 1.3 & 33 & 20 \\
\hline & \multicolumn{8}{|c|}{ Low Blological product Ivity perlod (December 1973) } \\
\hline Prerelease $(\mathrm{pcl} / \mathrm{kg})$ & ND & ND & 11 & 13 & $3.3^{d}$ & ND & $40^{\mathrm{d}}$ & $22^{d}$ \\
\hline Postreiease (pci/kg) & 1,1 & 1.1 & $9^{d}$ & 25 & $4.3^{d}$ & ND & 67 & 67 \\
\hline Rate $(\mathrm{pCl} / \mathrm{hr})^{\mathrm{C}}$ & 0.37 & 0.37 & - & 4.0 & $0.3^{d}$ & - & $9^{d}$ & $15^{d}$ \\
\hline
\end{tabular}

\footnotetext{
"Noraalized: measured concentration $(\mathrm{pCl} / \mathrm{kg})$ divided by expected concentration in discharge canal mater ( $\mathrm{pCl} / 1 \mathrm{fter}$ ).

bot detected.

CAmount accumulated per hour during the release.
} 
of accumulation by $65 \%$ for ${ }^{54} \mathrm{Nn}$, by $90 \%$ for ${ }^{60} \mathrm{Co}$, by $40 \%$ for ${ }^{65} \mathrm{Zn}$, and by 30\% for ${ }^{137} \mathrm{Cs}$.

In the December experiment, the oysters were placed in the discharge canal at 1230 on December 3. The prerelease oyster sample was taken 8-1/2 hr later, at 0900 on December 4, and the postrelease sample 3-1/2 hr after that, ot 1230 on the same day. The results are given in Table 10. In the prerelease sagples, ${ }^{54} \mathrm{Mn},{ }^{60} \mathrm{Co}$, and ${ }^{65} \mathrm{Zn}$ were detected in oysters from unfiltered water, but only ${ }^{54} \mathrm{Mn}$ and ${ }^{65} \mathrm{zn}$ were decected in thoze from filtered water. The rates of accumulation in the oyster during the release per lod were higher in July than in December for all the radionuclides except ${ }^{137} \mathrm{Cs}$. For ${ }^{137} \mathrm{Cs}$, the accumulation rates were very similar during both periods, suggesting that the higher July rates for the others reflected differences in radionuclide arallabllity rather than different conditions in tire aquaria and cages, The differences in accumulation rates between July and December were greatest in unfiltered water, again except for ${ }^{137} \mathrm{Cs}$. The Decewber rates were iower by $100 \%$ for ${ }^{54} \mathrm{Nin}$ and ${ }^{60} \mathrm{Co}$ and by $70 \%$ for ${ }^{65} \mathrm{Zn}$; they were essentially the sane for ${ }^{137} \mathrm{Cs}$.

In the December experiment, three additional postrelease samples of oysters were taken during the three days following the release. Figure 7 shows the relationship between the radionuclide concentrations in the wyster solt fissues in atl flve samples and the concentrations in the suspended partculaces during che same period. (Note that the values plotted In the graph are not normallzed and therefore not directly comparable to those normalized values in Table 10.) In the oyscers the four radlonuclides exhlbit quite dffferent patterns of accuaration and $108 s$ in relation co thele concencracions in the particulates.

\section{${ }^{137} \mathrm{Cs}$}

The concentrations in the oyaters were essentially unaltered by filtration of theit seawater medium. In both medla, the concentration in the oysters rose very sharply during the release, then decreased rapldly during the next $24 \mathrm{hr}$ and such more slowly during the subsequent days (Flg, 7). The concentrations in the partlculates were elevated during the release but fell off immediately thereafter, except for small increases hetween the hithhigh tides and the succeeding low tides.

\section{$657 \mathrm{n}$}

The patterns of accumulation and release by oysters were considerably altered by iltration of the medium (Fig. 7). The slower decreases in concentration in unfiltered water appeared to reflect continued Input 

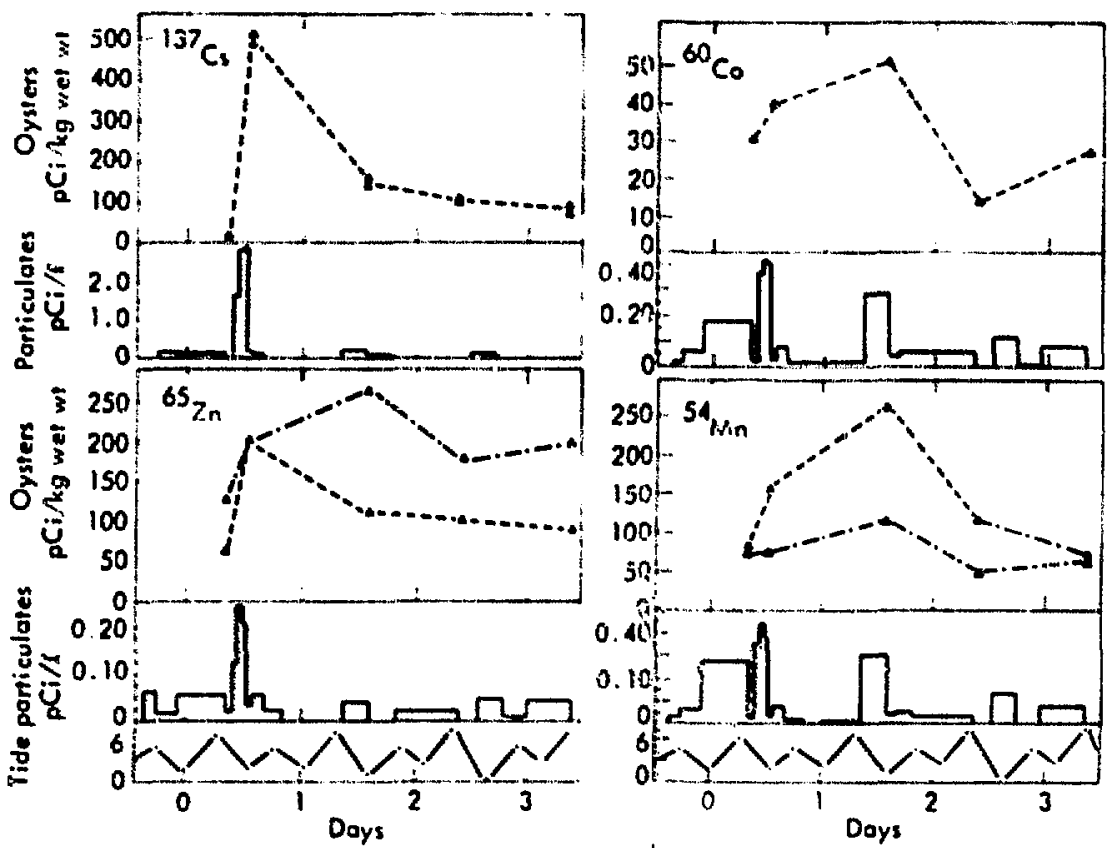

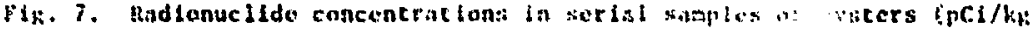
wet we) and suspended particulates (pel/i) collectod duriag the becerber

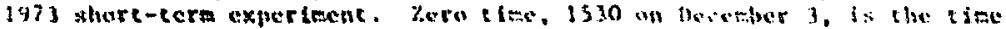

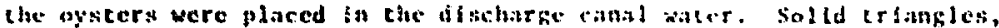

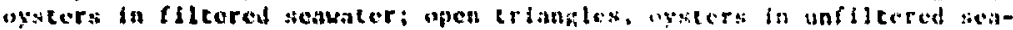

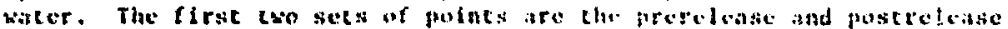

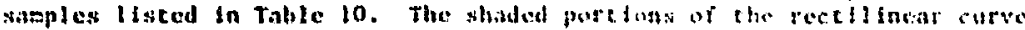
istupended pareleulaces) Indicats: the relsase tacervals.

of ${ }^{65} 7 \mathrm{n}$ fron the suspended particulates, wisi almost abseat in oysters fros whero perlodic increanes tany bear some lilcered water (sce Table 10). In relation to changes in the adal cycle. the suspended particulaces, concen-

${ }^{60} \mathrm{co}$

In the oysters in unf 11 tered watec, changes in concentration were Irregular and clearly reflected changes in the concentrations in the particulate froction ( $F$ sh. 7$) ;{ }^{60} \mathrm{Co}$ crations were clevated over several of the sampling perlods following the release; choy were highest in chose samples collected between a lifgh-high cide and the subsequent low cide. The perlodicity of the changes sugest that the varlations 
ate related to changes in the tidal cycle. The relatively high concentrations in the prerelease samples are probably attributable to the two preceding releases $(16,000 \mu \mathrm{Cl}$ on November 27 and $4000 \mu \mathrm{CI}$ on November 30). The quantitiea were much higher than in the December 4 iclease ( $780 \mathrm{\mu C1}$ ); the diacharge canal sediments probably contained a constderable amount of residual ${ }^{60} \mathrm{Co}$. Consequently, the accunulation during the December experiment appears to reflect not only the December 4 release but the preceding two releases as well.

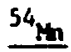

Filtration of the seawater mediun affected the rate and maximum level of ${ }^{54} \mathrm{~km}$ accumulation in the oysters, but the two curvea are similar in shape, In both cases reflecting changes in the suspended particulates (F1g. 7). As with ${ }^{60} \mathrm{Co}$, concentrations in the particulates were relatively high in the prerelease sanplea, probably because of the large quantities of $54 \mathrm{th}$ in the two preceding releases $(11,500 \mu \mathrm{Cl}$ on November 27 and $2800 \mu \mathrm{CI}$ on November 30 ; only 520 $\mathrm{Cl}$ was reieased on December 4 ).

\section{Long-Term Accumulation}

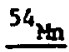

During the first 12 months of the experiment, concentrations of ${ }^{54} \mathrm{Mn}$ In the oysters were generally several hundred plcocurles per kllogram wet weight (Fig, 5). During purlods of low release rates, concentrations were below detection limits. After the serles of large releases in the Fall of 1972, concentrations in the oysters reached more than $1700 \mathrm{pCl} / \mathrm{kg}$. The particulates as well as the oysters reflected the quantities released, but concentrations in the oysters were lowered and less varlable than those in the settled particulates (pC1/kg dry welght).

\section{${ }^{65} \mathrm{2n}$}

Concentrations of this radionuclide were about $10 \mathrm{times} h \mathrm{hgher}$ and were less vartable than those of ${ }^{54} \mathrm{Mn}$ (FIg. 5). The differences between ${ }^{54} \mathrm{Mn}$ and ${ }^{65} \mathrm{Zn}$ were greater than expected frot the average concentratlons released (Table 2), suggegting that the two nuclides have different tretabolic pathways. As with ${ }^{54} \mathrm{Mn}$, concentrations in the oysters reflected changes In the quantities released; the maximum $(100,000 \mathrm{pCl} / \mathrm{kg})$ was in December 1972 .

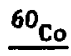

Concentrations of ${ }^{60} \mathrm{Co}$ were. lower and more yariable than those of ${ }^{65} \mathrm{Zn}$ (F1g. 5). The average quantity released was greater for ${ }^{60}$ Co than for ${ }^{65} \mathrm{Zn}$ (Table 2), but 
${ }^{60}$ Co corcentrations in the oysters were less than $1000 \mathrm{pCl} / \mathrm{kg}$ except in the laall of 1971 and 1972 when the releases were larger and more frequent.

\section{${ }^{137} \mathrm{Cs}$}

Concentrations of ${ }^{137} \mathrm{Cs}$ in the oysters were generally less than $100 \mathrm{pCl} / \mathrm{kg}$ (Fig. 5), even though the average quantity released was cortsiderably greater than for the other radionuclides (see Table 2 ). During the Summe' of 1972, concentrations in the oysters were belor. detection levels.

\section{Concentration Factors}

Comparisons of the concentrations of radionuclides in the oysters to those ia the water provide an indication of the ability of the oysters to accumulate the radionuclides. Calculations of concentration factors for the discharge canal oysters were complicated by the absence of steadystate conditons in the ecosystem due to the irregularity of the releases and the changing hydrological conditions. However, concentration factors were calculated for each sampling interval over the 18-month experimental period, by dividing the concentrations in the oysters by the average expected concentrations (see Eq. (1)) of the water during the period preceding their removal. The periods between oyster samplings ranged between 21 and 49 days. During the 18-month period, the average concentration factor (CF) was about 18,000 for ${ }^{54} \mathrm{Mn}$, about 6000 for ${ }^{60} \mathrm{Co}$, about 120,000 for ${ }^{65} \mathrm{Zn}$, and about 50 for ${ }^{137} \mathrm{Cs}$.

\section{Discussion and Conclusions}

The radionuclide burdens in seafood animals living in waters adjacent to nuclear power plants are dependent on the concentrations of radionuclides in the environmental water and on their availability to food-chain organisms. The concentrations in water are dependent on the quantities released, the specific hydrodynamic conditions, and the interactions of the radionuclides with the particulates in the system. The zvailability is dependent in part on the physicochemical form of the radionuclide in the water.

SEAWATER

Radionuclide concentrations is the seawater of the Humboldt Bay environment varfed widely with site and with time. Some indication of the expected differences in ${ }^{137} \mathrm{Cs}$ concentration with site can be obtained from Fig. 8, where average concentration values for 
${ }^{137} \mathrm{Cs}$ are plotted for the waste water and the successive altes of dilution: the discharge canal, Central Bay, and thuboldt Bay as a whole. For these calculations it was assumed that there was Instantaneous dilution Into each successive body of water and that the radionuclides from one release were totally wished out before the next release occurred. The largest reduc- tion in concentration resulted from the dilution of the llquid waste by the cooling water.

The concentrations of radionuclides at each dilution site varied considerably with time due to differences in the amounts released, in the conditions of the release, and in the frequency of release. The greatest var!ation resulted from the differences in the

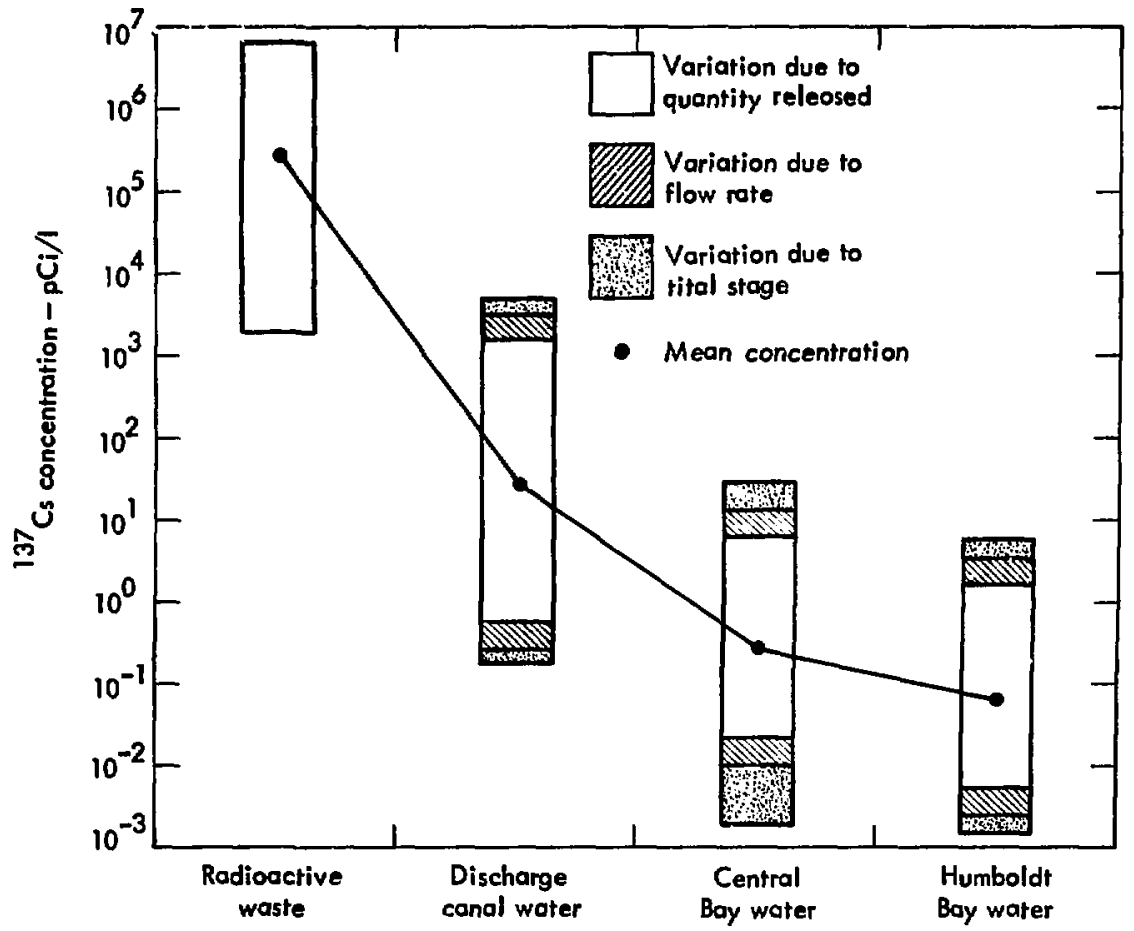

F18. 8. Changes in ${ }^{137} \mathrm{Cs}$ concentration at successive dilution sites in its passage from the reactor to Humboldt Bay. Points, mean concentrations; bars, variations due to differences in quantity releașed, flow rate of cooling water, and stage of tidal cycle. 
quantities released; for ${ }^{137} \mathrm{Cs}$ the minimum was $66 \mu \mathrm{Ci}$ and the maximum was $151,000 \mu \mathrm{CI}\left(\mathrm{Fig}_{\mathrm{g}}, 8\right)$. The varlation due to differences in flow rate through the canal was about a factor of 2; the minimum dilution factor was 2406, the maximum was 5170. The variation due to stage of tidal cycle at the time of releese was about a facter of 2 for Central Bay and about 1.7 for Humboldt Bay as a whole. The variations in concentration due to differences in the frequency of release were less than those due to the quantitles released but more than those due to changes in flow rate and stage of tidal cycle. The minimum interval between releases was one day, the maximum was 34 days.

$$
\text { Because }{ }^{54} \mathrm{Mn},{ }^{60} \mathrm{Co} \text {, and }{ }^{65} \mathrm{Zn}
$$

interact with particulates in the sea water, their concentrations at different sites might be expected to vary more than that of ${ }^{137} \mathrm{Cs}$ or that predicted by hydrodynamic conditions and the quantities released. On the average, measured values were more variable and lower during release periods and higher between release periods. The lower concentrations during release periods may be a result of radionuclide binding to particwates on the botton and sides of the canal upstream from the sampling station. If such depletion of radionuclides from the water occurs, the discrepancy between measured and expected concentrations of radionuclides with a high affinity for particles might increase with distance from the source. No measurements were made to test this hypothesis.

Measured and expected radionuclide concentrations were compared during release of water from the coolar:i canal of the Oyster Creek nuclear rower plant in Ocean County, New Jersey, 9 For radionuclides that were retained quantitatively on filters and Ionexchange columns, the ratios of measured to predicted values were 0.6 to 1.2 with one exception. During one discharge, ratios were four to flve times lower than expected. Deviations from a ratio of one we:e attributed to the following uncercaintiles in these measurements :

- dilution factors based on nominal values of waste release and canal water, assumption of a homogeneous mixing of waste and canal water, posstble deposition of radionuclides from canal water prior to sampling or resuspension from the canal sediment, recirculation effects not measured simultaneously with discharge canal sampling, and low concentrations of radionuclides in liquid wastes following dilution with sea water. 
In both this study and the one at Oyster Creek, ${ }^{9}$ the largest fraction of radionuclides in the sea water of the dtacharge canal during releases was ansoclated with the particulates. In the Oyster Creek study, 60 to $100 \%$ of the ${ }^{51} \mathrm{Cr},{ }^{54} \mathrm{kn}$, and ${ }^{60} \mathrm{Co}$ and large fractions of ${ }^{95} \mathrm{Nb},{ }^{95} \mathrm{zr},{ }^{140} \mathrm{Ba},{ }^{141} \mathrm{Ce}$, and ${ }^{144} \mathrm{Ce}$ ware assoctated with particles. Thus, in model development, It 1s Important to consider that gone elements do not behave conservatively, 1.e., their concentrations are not directly proportional to the salinity of the water. Consequently, their concentrations cannot be calculated as ample dilutions of the source material. In addition, dilution parameters may vary from one site to another, and blological and geochemical factors may change with time.

\section{PARTICULATES}

The particulates in the discharge cannl can be considered to be in two compertments, suspended and settled; redilonuclides are constantly interchanged between the two compartments. The dynanics of Interactions in the discharge canal were investigated by following the changes in radionuclide concentrations in the two compartments subsequent to scheduled releases.

\section{Suspended Particulates}

Comparisons of measured radionuclide concentrations in the soluble and/or particulate phases of the water at any tine for a given release indicated that the radionulcides differed in their affinities for the particulates. These differences in affinity are ralated to the chemical properties of the radionuclides and were in the same order $\left({ }^{54} \mathrm{Nn}>{ }^{60} \mathrm{Co}>{ }^{65} \mathrm{Zn}>{ }^{137} \mathrm{Cs}\right) \mathrm{as}$ the sequences determined by others for the distribution coeffictent of the gene radionuclides. 6,7

Radionuclide concentrations in the suspended particulstes ( $\mathrm{PCl} / \mathrm{l}$ ) varied greatly from one release to another. These differences probably were due to differences in particle glze and composition, which in turn undoubtedly depended on blological processes occurring In the south part of Humboldt Bay. S1-.e South Bay is ghallow, light easily penecrates to the bottom; the mud flats support extensive beds of eelgrass. Messurements of phytoplankton productivity and eelgrass standing stock during the previous year (1972) Indicated higher blological activity in July and August than in December. 10 Increases in phytoplankton productivity would have resulted in direct Increases in suspended particulates; Increases in eelgrass standing stock would have resulted in indirect Increases (suspended detritus from the decomposition of decay ing plant material).

Fadionuclide concentrations for a given radionuclide also were observed 
to change with time in the suspended fartirulaces subsequent to releases. These changes are probably attributable to variacions in the rate of resuspenslon of the bottom sediments, in the amounts of radionuclides bound to these sediments, and in tho quantities of unlabeled particulates in the inflowing water. Another posstble source of these changes may be the Influx of radloactive particles contained in water flowing into the discharge canal. There is evidence of recirculation of water from the discharge canal. 11,12 This recirculation appears to take place under certain tidal conditions and is not a general occurrence; however, when it does occur, the inflowing water may contain both radioactive particles from the discharge canal and unlabeled particles from the Bay.

The largest fraction of the radioactivity in the suspended particulates was collected on the 10- $\mu \mathrm{m}$ filters. These larger particles would tend to settle out more rapidly than the smaller ones and thus would be more likely to be present in greater quantity in the settled particulates in the discharge canal and its vicinity than in the settled particulates in the open Bay.

\section{Settled Particulates}

The bottom sediments in the discharge canal represent a pool of particulate-bound radionuclides that appears to control the concentrations of radionuclides in the water between releases. Resuspension of these bottom sediments is affected by the flow rate of the cooling water into the canal and by the tidal level and wive action of the water in the bay. In the interval between releasts time-related decreases with time in the in the radionuclide concentrations of the particulates that settled on the bottom were probably due to dilution with nonradioactive particles present in water flowing in from the Bay as well as to desorption of radionuclides. Measurements of the particulate loads in the Intake canal water Indicated that the unlabeled particulates in the Intake canal water were sufficient in quancity to reduce the radionuclide concentrations in the bottom sediments when they were mixed with them.

Bottom sediments can be considered to consiat of a historical (unmixed) layer and $a$ mtxed layer. ${ }^{13}$ In the discharge canal the homogeneity of the mixed layer depends not only on physical and chemical processes but also on the frequency of the radioactive releases and the magnitude of the variations in quantity discharged from one release to another. If the mbed layer is heterogeneous and the depth of scouring varies with tidal cycle and flow rate, one would expect 
variations in radionuclide concentration like those observed there in che particles deposited on the suspended trays and separated on our filter cartridges.

During the 34-day Interval after June 13, 1972 when no releases occurrer, the radionuclide concentratlong changed very little in the setiled particulates collected on the suspended trays; they were not signifIcantly lowar than at other times. In this case, the absence of a large decrease may be related to the rates of tumover of radionuclides in partisulates. Let us consider briefiy radionuclide turnover in particul.s.tes In the discharge canal, Uptake and loss of radionuclides by partir.les involves both relatively rapld reactions and slow reactions. 14 The more rapid include ton exchange reaistions and nonspectfic absorption reastlons. The slow reaci:lons include perietrations into the interstices of crystal matrices and Into the broken ends of crystal lattices, and/or penetration through the thin layer of organic material covering the particles.? W1th each new ralease in the discharge canal, the bottom particulates were exposed to elevated radionuclide concentrations, and the overall result was periodic increases and decreases in the radionuclide concentrations in these parciculates. However, if the intervals between releases were about the same, and if the quantities released differed by less than an order of magnicude, then the concentrations of the interstitial water of the sediments probably remained htgh enough for sufficiently long periods to permit relatively complete labeling of those particulate compartments with slow turnover times. Such a series of releases occurred before the 34-day interval wthout a release that followed the release of June 13,1972 . Consequently, concentration changes over most of this interval probably were due prinarily to loss of radiowilides from compartments with slow turnover rates. Thus, one would expect only small changes with tine.

Another long Incerval without a release occurred after the release of October 6, 1972. Large decreases in radionuclide concentrations were observed in the settled particulates in the 21-day interval following this release. These changes probably resulted from the desorption of radionuclides from the compartments with rapid turnover times; the latter had been labeled by the exceptionally large amounts of radionuclides in the release. However, the uptake of radioactivity by particulates appeared to be considerably more rapid than its loss. The seawater maintatned its high radioactivity levels only during the six hours of the release, but the particulates remained higher than in 
the prerelease period for the entire 21-day interval until the next release. These data indicate that the half-time of radionuclides is considerably longer in the particulate campartment than in the water.

The relationships among the soluble phase in the water, suspended particulates, and settled particulates can be summarized as follows. Suspended particulates in the discharge canal water appear to be derived from two sources: Inflowing water from the Bay and bottom sediments. During release periods, the radionuclide concentrations would in general be higher in the inflowing water than in the bottom sediments, whereas during interrelease perfods the reverse would be expected. If over a given interval of time, whether during or between releases, there is a constant rate of influx of particles from the Bay and a constant rate of resuspension of bottom sed1ments, changes in radtonuclide concentrates in serial samples of the suspended particulates can be attributed to adsorption and desorption reactions, However, the contribution from the two sources may differ because of changing hydrological conditions in the Bay and/or in the discharge canal. The relationships among the abiotic compartments in the discharge canal are summarized in Fig. 9. The interactions shown take place for all the radionuclides, but the fractionation among the compartments differs from one radionuclide to another and from one time to another. These differences are due to the differing affinities of the radionuclides for particulates and to seasonall changes in the composition of the particulates.

\section{OYSTERS}

The availability of radionuclides to filter-feeding aquatic organisms is determined in part by the amount of particulates in the water - living microorganisms, organic detritus, inorganic material, or any combination of these. The quantities of suspended particulates in the water column can vary both in time and in space.

The suspended material available to oysters in the discharge canal cane from two sources: particulates resuspended from the materlal deposited onto the hottom and particulates carrled in with the inflowing water. Resuspension of bottom sediments appears to be related to changing hydrological conditions in the bay and in the discharge canal. The particulate load in the Inflowing water is probably dependent on biological and physical processes occurring in South Humboldt Bay.

The differences in accumulation between July and December were probably due to differences in both the 
Liquid waste

+ coolont water
Interactions within discharge conal
Seawater + waste entering Central Bay
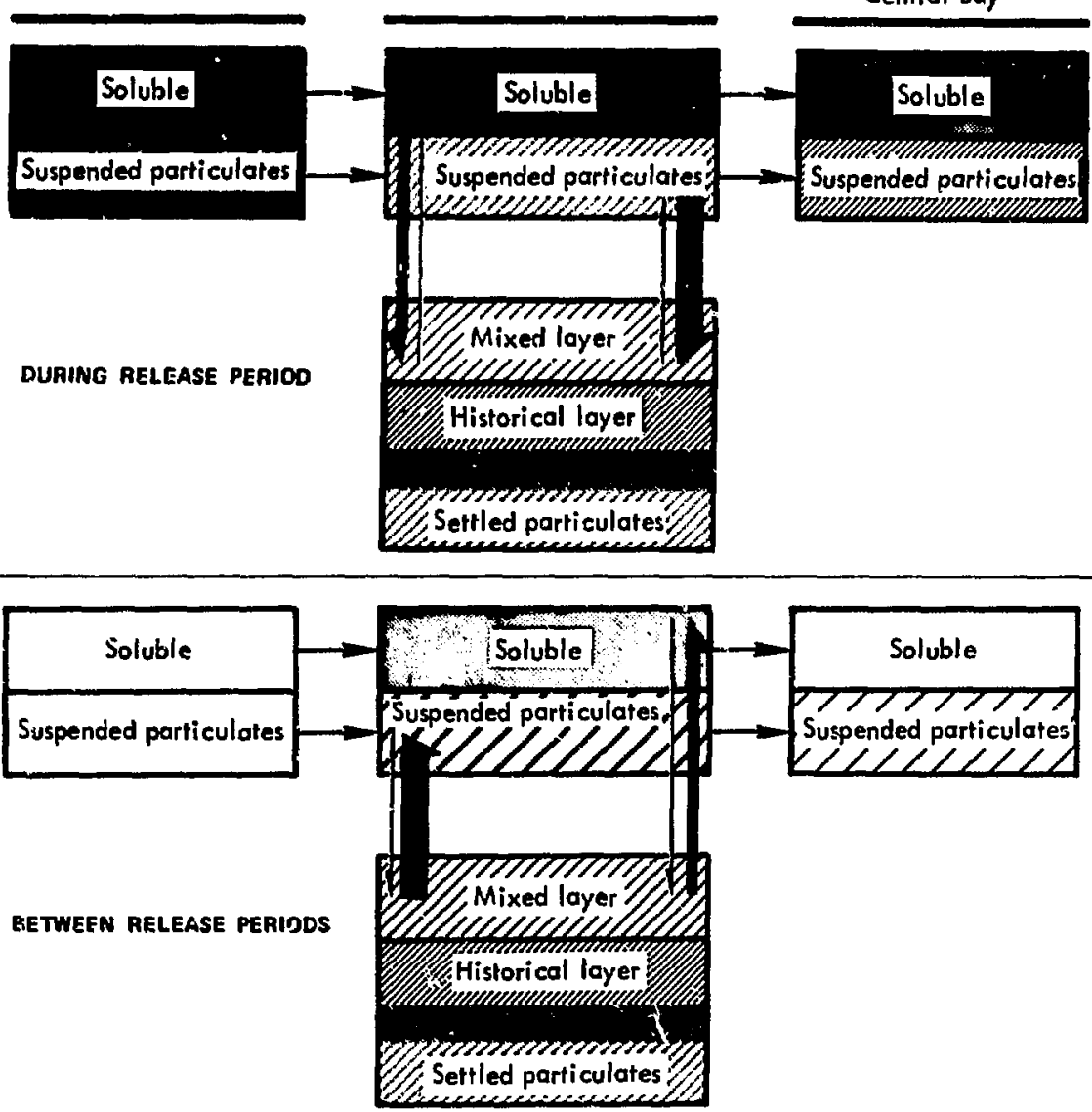

Fig. 9. Dynamics of interactions of radionuclides among the soluble and particulate phases in the discharge canal of the Humboldt Bay reactor. The soluble and particulate compartments are represented as equai in size for simplicity's sake, but in reality the distribution between them differs from one radionuclide to another. For example, the solubie fraction may contain more than $95 \%$ of the total ${ }^{137} \mathrm{Cs}$, but only about $50 \%$ of the total $60 \mathrm{Co}$. The intensity of the stippling or shading approximately reflects the difference in concentration between one compartment and another. The major direction of movement from one compartment to another is indicated by the heavier arrows. 
quantity and composition of the particulates in the water. Both these parameters are related to changes in production in phytoplankton and eel grass in the Bay. The differences between July and December may be related also to the levels of stable elements in the water. This factor would be important for any element whose concentration in the oysters is under metabolic regulation. For such elements, the rate of radionulctde accumulation would be expected to change with changes in the proportion of staile nuclide in the water: the accumulation per unit quantity of radionuclide released would decrease with increased concentrations of the stable nuclide in the water. For elements whose concentration in the oyster is not under homeostatic control (no regulation), but is dependent on the amount present in the water, the accumulation per unit quantity of radionuclide released would be independent of the concentration of the stable element in the water.

Little information is avallable on the regulation of $\mathrm{Mn}, \mathrm{Co}, \mathrm{Zn}$, or Cs in oysters. It has been calculated that in is accumulated in oysters to levels much higher than those required for metabolic functions. 15 Shuster and Pringle ${ }^{16}$ report that, in general, for each doubling of the environmental level of a trace metal, the tjissue level of the metal approximately doubled in Crassostrea virginica. Their results obtained from a series of experiments ${ }^{16-18}$ suggest that in this oyster there is little or no regulation of tissue concentrations of $\mathrm{Cd}, \mathrm{Cu}, \mathrm{Cr}, \mathrm{Pb}$, or $\mathrm{Zn}$.

It has been established for many bivalve molluscs that the presence of food material in the water stimulates their circulation of water for feeding as well as respiration purposes. 19-21 Because primary productivity in Humboldt Bay is considerably greater in July than December, it is very probable that in July more of the oysters in the discharge canal would be circulating seawater for feeding. The differences in accumulation between the July and Decenber animals are probably related to the food material. present in the water.

From these experiments, the role of particulates in radionuclide accumulation appeared to differ with the radionuclide. In oysters, ${ }^{60}$ Co appears to be accumulated primarily from the suspended particulate fraction whereas ${ }^{137} \mathrm{Cs}$ appears to be accumulated primarily from the soluble fraction; ${ }^{54} \mathrm{An}$ and ${ }^{65} \mathrm{Zn}$ accumuiation are between these two extremes. Since the particulates vary in amount and composition both temporally and spatially in an environment, the quantities accumulated by organisms wouid vary correspondingly for those radionuclides with high affinities for particulates. The 
importance of particulates in the accumulation of ${ }^{65} \mathrm{Zn}$ by oysters is confirmed by Preston, 22 He found that In the River Blackwater estuary, the concentrations of ${ }^{65} \mathrm{Zn}$ were related to the silt and were poorly related to the expected distribution of Ionic zinc in the seawaser.

The turnover rates of radionuclides have been measured recently in bivalve molluses both in the field ${ }^{23-26}$ and In the laboratory. ${ }^{27-33}$ In the fleld, ecological half-1lves of ${ }^{65} \mathrm{z}$ have been measured 23,24 as well as effective and biological half-1ives. 25 our results Indicate that the turnover rates obtained in the field should vary with the season; such variation Is suggested by the turnover rates obaerved for ${ }^{65} 2 n$ in oysters. ${ }^{25}$

Turnover rates determined in the laboratory would be expected to vary with the kinds and amounts of particIlates available for food. Some recent reports have considered the effects of food and water on tumover rates. Romer $\$ 1^{27}$ attributes the differences between his observed turnover rates and concentration factors and other results obtained in the fiteld under natural conditions to be due to the virtual absence of the ingestion pathway under his experi- mental conditions. Renfro et al., 34 state that for certain animals such as shrimp, the food pathway appears to play a less important role in zinc accumulation than had been gensrally accepted. On the other hand, Rice and Baptlst ${ }^{35}$ reporced that Antemia incoiporated ${ }^{65} 7 \mathrm{n}$ much faster from food than water. However, more information is needed on turnover rates under varying environmental conditions In the field and under difierent controlled feeding regimes in the latoratory before the proper rates can be selected for blological modelisg.

The stable-element $C \vec{r}$ values for this spectes are consiterably lower than those calculated for the radionuclides. The stable $C F$ values are approximately 1000 for $\mathrm{Mn}, 300$ for Co, 10,000 for $\mathrm{Zn}$, and 15 for $\mathrm{Cs} .{ }^{36}$ The differences between the stable and radloactive isotope concentration factors are in the order ${ }^{60} \mathrm{Co}>{ }^{54} \mathrm{Mn}>{ }^{65} \mathrm{Zn}>{ }^{137} \mathrm{Cs}$. These data suggegt that the radionuclides avallable to the oysters are higher in concentration than those calculated from the dilution of the source (expected water concentrations). The greater availabllity is related to the resuspension of radioactive bot tom sediments during interrelease periods. 


\section{Acknowledgments}

The authors thank the staff of the Paciftc Gas and Electrtc Company (Department of Englneering Research, and Humboldt Bay Power Plant) for thetr cooperation and assistance.
They also acknowledge the assistance of John Dawson, Rodney Eagle, Gale Holladay, Learh Nelson and William Stecle of this Laboratory in the collection and preparation of samples. 


\section{References}

1. R. E. Heft, F, L. Harrison, and W. A. Phlllips, "Rndloecologlcal Study of the Humbolde Bay Marine Environment." Broc. Hm. Huelear Society Hecting

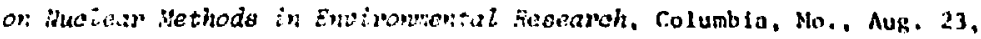
1971; also Lawrence Livermore tahoratory, Preprint UCkL-73]68 (1971).

2. R. F. Heft, W. A. Phillips, H. R. Ralston, and W. A. Steele, "Kadinlluclide Transport Scudies in the Humboldt Bay Natind linvironment." In spmasiz"

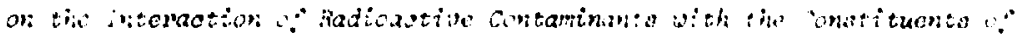

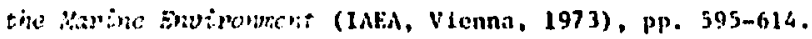

3. C. Holladay, P. L. Whelpr, R. E. Heft, and F. L., Itarrison, "Instrumentitton for a Radioecological study of the llumboldt Bay Marine Environment," EEEE TYans. HS- 29,245 (1972).

4. V. E. Noshkin, F. L. Harrison, R, E. Heft, K. M. Wong, Enviponmenta?

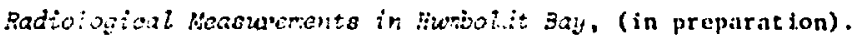

5. G. Huckabay, Lawrence Livermore Laboracory, personal communication (1975).

6. E. K. Duursma and D. is lsma, "Theoretical, Experimental and Field Studies Concerning Reaction of Radioisotopes with Sediments and Suspended Particles of the Sea. C. Application to Field Studies," Netieriands 7. Sea Rea. 6. 265-324 (1973).

7. E. K. Duursma and M. G. Gross, "Marine Sediments and Radioactivicy," in Radioactivity in the Harine Environment (National Academy of Sciences, Washington, D.C., 1971).

8. F. L. Harrison, "Btological Implications of Nuclear Debris in Aquatic Ecosysters," Vucl. Fechnol. 11, 444-458 (1971).

9. R. L. Blanchard, W. L. Brinck, H. E. Kolde, H. L. Krieger, D. M. Montgomery S. Gold, A. Martin, B. Kahn, Radiological Sumeillance Studies at the Oyster Creek Bhi? Wuclear Generating Station, U.S. Fnvironmental Protsction Agency, Rept, EPA-520/5-76-003, 1976.

10. L. W. Harding, Jr. J. H. Butler, and R. E. Heft, The Standing Stock and Production of Eeigrase (Zostera marina L.) in Humboldt Bay, Califomia, Lawrence Livermore Laboratory, Preprint UCRL-76987 (1975).

11. K. M. Wong, V. E. Nosthin, and G. Holladay, Lawrence Livermore Laboratory personal communication (1975).

12. D. P. Serpa, Pacific Gas and Electric Company, San Ramon, Californta personal communication (1975). 
13. 6. F. Lee, "Factors Afecting the Transfer of Materials between kiter and

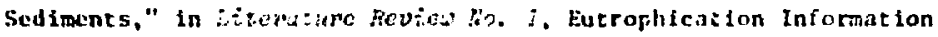
Program Woter Resources Center, tinlucrsity of Hisconsin, Madison (1970), np. $1-35$.

14. F. K. Duursma and C. J. Bosch, "Theoretical, Fxperimental and Field studles Concerning Diffusion of Radiotsotopes in Sediments and Suspended Particles

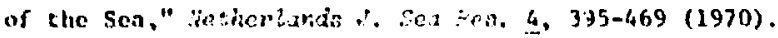

15. J. F. Pequegnat, S. W. Fowler, and i. F. Small, "Esctmates of the Zine

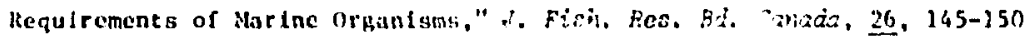
(1969).

16. C. N. Shuster and R. I1. "ringle, "Trace Metal Aecumulation by the American

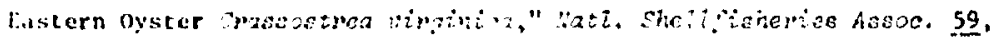
91-103 (1969).

17. B. H. Pringle, D. E. Hissong, E. L. Katz, and S. T. Mulawka, "Tra,.. Metal Accumulation by Estuarine Mollusks," \%. Canit. Eng. Div. (Eroa. Ar. Soo. Eivil Engt) 94, 455-475 (1968).

18. C. N. Shuster, Jr., and B. H. Pringle, "Effects of Trace Metals on Estuarine Mollusks," troc. Ist Cons on Mil-itlanti: Naste, Untversity of Delaware (CE-5) (1968), pp. 285-304.

19. P. S, Galtsoff, "The American Oyster Crasestrea vinginica Gmelin," $U .3$. Fish, Wildl, Serv. Fish. Bull, 64, 1-480 (1964).

20. I. R. Rice and R. J. Smith, "Filtering Rates of the Hard Clam (Venus mercenaria) Decermined with Radloactive Phytoplankton," U.S. Fish. Wildi. Serv. Fish. Buzz. 58, 73-82 (1958).

21. C. Davids, "Influence of Suspensions of Microorganisms of Different Concentrations on the Pumping and Retention of $F c d$ by the Mussel (Hytilus eduliss L.)." Netherlands J. Sea Res. 2, 233-249 (1964).

22. A. Preston, "The Control of Radloactive Pollution in a North Sea Oyster Fishery," Helgol. wiss. Meenesunter. 17, 269-279 (1968).

23. E. 0 . Salo and $W . L$. Lest, "The Concentration of ${ }^{65} \mathrm{zinc}$ by oysters Maintained In the Discharge Canal of Nuclear Power Plants," Proc. 2nd Nat2. Symp. on Radioecology, D. J. Nelson and F. C. Evans, Eds. (Natlonal Technical Information Service, Springfield, Va., 1967), pp. 363-371.

24. D. A. Wolfe, "Levels of Stable $\mathrm{Zn}$ and ${ }^{65} \mathrm{Zn}$ in Crassostrea virginica from North Carolina," J Fish. Res, Bd, Canada 27, 47-57 (1970).

25. A. H. Seymour and V. A. Nelson, "Blological Half-lives for Zinc and Mercury in the Pacific Oyster, Crassostrea gigas," in Proc. 3rd Natz. Symp. on 
Racioecology (National Technical Information Services, Springfield, Va., 1972). pp. 849-856.

26. A. H. Seymour and V. A. Nelson, "Decline of ${ }^{65} \mathrm{Zn}$ in Marine Mussels Following the Shutdown of Hanford Reactors," in sump on tine interaction of Radioative concaminants with the constituent o:" the linine Environment, (IAEA, Vienna, 1973), pr. 277-28i.

27. H. G. Romer11, "The Uptake and Distribution of "2n in Oysters," Mar. Riol. 9. 347-354 (1971).

28. C. L. Schelske, "Fallout ${ }^{54} \mathrm{Nn}$ Accumulated by Bay Scallops Aropecten impadians (Lamarck) near Beaufort, North Carolina," in "igm, on Interaction of Racioactive Contaminants with the Conetituente o; the Marine Envizonnent (IEAE, Vienna, 1972), pp. 331-346.

29. R. J. Pentreath, "The Accumulation from Water of ${ }^{65}$ Zinc, ${ }^{54}$ Nanganese, ${ }^{58}$ Coba2t, and ${ }^{59}$ Iron by the Mussel, Mytilus edulis," I. Mar. Biol. Assoc. U.K. 53, 127-143 (1973).

30. R. J. Fentreath, "The Role of Food and Nater in the Accumulation of Radionuclides by Marine Teleost and Elasmobranch Fish," in symp. on the Irteraction of Contaminants with the Constituents of the larine Environment (IAEA, Vienna, 1973), Pp, 421-436.

31. A. W. Van Weers, "Uptake and Loss of ${ }^{65} \mathrm{Zinc}$ and ${ }^{60}$ Cobalt by the Mussel Mytilus edutis," in Symp. on the Interaction of Radioactive Contaminants with the Constituents of the Harine Environment (IAEA, Vienna, 1973), PP. 385-402.

32. F. L. Harrison, "Accumulation and Loss of Cobalt and Cesium by the Marine clam, Mya arenaria, under Laboratory and Field Conditions," in nymp. on the Interaction of Radioactive Contaninants with the Constituents of the Marine Environment (IAEA, Vienna, 1973), Pp. 453-478.

33. G. Cranmore and F. L. Harrison, Loss of ${ }^{137}$ Cesium and ${ }^{60}$ Cobalt from the Oyster Crassostrea gigas," Health phys. 28, 319-333 (1975).

34. W. C. Renfro, W. S. Fowler, M. Heyraud, and J. LaRosa, "Relative Importance of Food and Water Pathways in the Blo-accumulation of 2 inc," in Activities of the Intemational Laboratory of Marine Radioactivity, 1974 Report (IAEA, Vienna, 1974), PP. 11-20.

35. T. R. RIce and J. P. Baptist, "Ecological Effects of Radioactive Emissions from Nuclear Power Plants, in Human and Ecological Effects of Nuclear Power Plants, L.A. Sagon, ed. (Thomas, Springfield, I11., 1974), PP. 373-439. 
36. F. L. Harrison and R. E. Heft, Larrence Livermore Laboratory, unpublished data (1977).

BKI/ compo/bh/lmc

$-43-$ 